\title{
Determinants of Capital Structure and Speed of Adjustment: Evidence from Iran and Australia
}

\author{
Alexis Kythreotis ${ }^{1}$, Bagher Asgarnezhad Nouri ${ }^{2} \&$ Milad Soltani ${ }^{1}$ \\ ${ }^{1}$ School of Business Management, European University of Cyprus, Nicosia, Cyprus \\ ${ }^{2}$ School of Management, University of Mohaghegh Ardabili, Ardabil, Iran \\ Correspondence: Milad Soltani, School of Business Management, European University of Cyprus, Nicosia, Cyprus.
}

Received: December 7, 2017

Accepted: December 30, 2017

Online Published: January 22, 2018

doi:10.5430/ijba.v9n1p88

URL: https://doi.org/10.5430/ijba.v9n1p88

\begin{abstract}
This study investigated different companies' capital structures using a comparative approach in a developing country (Iran) and a developed country (Australia). The purpose of this study was to identify the factors affecting the capital structure based on the company's characteristics in Iran and Australia. The main characteristics of the companies used in this research are mainly based on the variables used in Pecking order theory and the Trade-off theory namely tangibility, firm size, profitability, and business risk. Three other variables including liquidity, asset utilization ratio and speed of adjustment were also investigated. Two indicators of total debt ratio and long-term debt ratio have been used as corporate leverage index. The population of this study included 178 Iranian companies listed on Iran's stock exchange and 187 Australian companies listed on Australia's stock exchange from 2009 to 2015. To test the hypotheses, Panel data and Eviews software were used. To ensure robustness of the results, the speed of adjustment was estimated using GMM and OLS (with fixed and random effects). The results of this study showed that dynamic trade-off theory could better explain the changes in capital structure in Iran and Australia. The results also revealed significant differences in factors affecting the capital structure in Iran and Australia.
\end{abstract}

Keywords: capital structure, corporate financing decision, the speed of adjustment, trade-off theory, the pecking order theory

\section{Introduction}

To maximize shareholder wealth, managers must attempt to obtain an optimal combination of company financing, in which the cost of capital is less than any other capital structure combination (Baker and Martin, 2011). Nevertheless, decision-making on capital structure puzzle has long attracted the attention of researchers (Myers, 1984). The complexity of decision regarding optimal capital structure is because the cost of financing varies by the characteristics of the company and is dependent upon factors such as the company's operational history, profitability, creditworthiness (Tugba, 2012).Capital structure is the mix of debt and equity of the financing organization (Pratt and Granbowski, 2010) and each financing method imposes its own cost on the company (Hitchner, 2017). Therefore, it is necessary to account for the cost of each component of capital structure. The components of the capital cost of a company are the cost of common stock, the cost of preferred capital stock, and the cost of debt capital. Financial managers must calculate the average cost of capital for each item about its proportion of financing, which is called the weighted average cost of capital (WACC). The importance of the WACC stems from the fact that the rejection or acceptance of proposed investment projects depends upon the comparison of the investment rate of return with the cost of capital. If the return on investment exceeds the cost of capital, the project is accepted, and if the return on investment is less than the cost of capital, the project is rejected (Mclean, 2003).

In general, three reasons have caused the capital structure to become a hot topic in the financial field. First, according to a series of surveys conducted by financial executives, there is a significant difference between the existing theories and the practice of capital structure in financial markets (see, for example, Graham and Harvey (2001). This may be because theories related to the capital structure in the subject in question are different. For example, the trade-off theory emphasizes the benefits and costs of the debt financing, while the pecking order theory addresses the costs of adverse selection, which result from information asymmetry between organizational managers and outside investors. (Hovakimian et al., 2004; Habibi et al., 2014). 
Second, research demonstrates that researchers have different views regarding the superiority of theories related to capital structure. For example, the study by Frank and Goyal (2008b, 2009c) supports the trade-off theory. Lemmon and Zender (2010) consider pecking order theory to be valid in financial decision-making, and Graham and Leary (2011) in their research conclude that the discrepancy between research results can be due to different methods of measurement of optimal capital structure.

Third, various analyses have been conducted regarding the 2008-2009 financial crisis. According to these researchers, the cause of the crisis is due to the wrong decisions made by executives regarding capital structure (See, for example, Miglo (2016). The financial crisis in America is one of the biggest economy-related disasters since the 1930s. Analysts have likened this crisis to a tsunami that began in the United States and spread to European countries and the rest of the world. Meanwhile, even the economies of the small countries had suffered (Fosberg, 2013).However, the effect of global financial crisis differs in across countries, due to the level of development of each country (Trinh and Phuong, 2016). For example, financial crisis has major in countries where bankruptcy laws and procedures are such that liquidation of the asset is costly. In this situation, both lenders and borrowers become reluctant in long-term investment (Demirguc-Kunt et al. 2015). In other words, the high cost of bankruptcy due to the inability of companies to repay their annual interest and principle payment, reduce the willingness of the companies to security issuance. In the same way, potential creditors expect the security of their investment will be less willing to lend to a company which is already highly geared (Fosberg, 2013). Therefore, in the first objective of this paper is attempted to identify the factors affecting capital structure to response to the question as to "why in different circumstances some companies choose to use the internal resource, others choose a debt method to fund their activities and some issue shares."This can assist managers in financial decisions and in preventing mistakes in decision-making regarding capital structure which lead to financial distress and devaluation of the company and reduction of shareholder wealth (Supra et al., 2016).

In another objective of the research, we intend to examine capital structure adjustment speed of companies. Huang and Ritter (2009) have argued that determination of adjustment speed has become a significant issue in today financial decisions made by managers and investors. The concept of the speed of adjustment is rooted in dynamic trade-off theory (Ghose, 2017). Accordingly, company financing policies are set to achieve target leverage ratio, which is specified through establishing a trade-off between the benefits of debt tax shield and the costs of bankruptcy (Supra et al., 2016). In other words, when the company deviates from the target leverage, it will have four options. When the company is over-leveraged, managers can retire debt or Issue new equity to return to the target leverage ratio; or, when the firm is under-leveraged, managers can repurchase shares or issue new debt to exploit the advantage of tax shield caused by debt increase (Oino and Ukaegbu, 2015). However, the process of capital structure adjustment may create costs for the company, and managers take action to adjust leverage ratio only when the benefits of capital structure adjustment are more than its costs (Fakhrhosseini and Sangdovini, 2016). Hence, knowing the adjustment speed, investors will be able to reduce investment portfolio risk through investing in companies that have a high adjustment speed. Likewise, considering the positive effect of adjustment speed on the company value, managers will be able to make better decisions regarding the capital structure and maximization of the company's values (Supra et al., 2016).The novelty of this paper comes from two aspects as follows,

\section{1) Cross countries comparison}

In general, there are two approaches to investigating factors affecting the capital structure in research. Some studies have investigated the factors affecting the capital structure in a single country, and others are based on cross-country comparisons. Look into these studies suggest cross-country comparison have some advantages over a single country analysis. The reason is that cross-country comparison can be used to create linkage between different determinant factors of capital structure among countries (Wald, 1999).

However, according to the author's knowledge, Iranian companies have not been included in any international or regional researchers (see for example Getzmann et al. (2014), Belkhir (2016) and Booth et al. (2001). One reason for this shortcoming is that the data of the companies listed on Iran stock exchange is native and the data is scattered across a variety of databases. On the other hand, most of the domestic researchers close with this scope are limited to a single country. To overcome this shortcoming, a cross-country comparison approach is used to compare the factors affecting capital structure based on corporate characteristics for developing a country of Iran and developed country of Australia.

2) Comprehensive and update database

The second aspect of innovation in this research is the use of variables that are less studied in analyses. This study follows the framework of Rajan and Zingles(1995) method four core factors (including Tangibility, Firm Size, 
Profitability, Business Risk) and two additional factors include Asset Utilization Ratio and Liquidity (Alipour et al. 2015) as explanatory variables to investigate determinant of capital structure.

By studying 149 research related to the capital structure in Iran (including Persian and English language), the frequency of each of the variables used in these studies was considered. As shown in the graph below, the four main factors (Risk, Size, Tangibility, Profitability, Liquidity) affecting capital structure are the most frequent. Also, two sub factors, the asset utilization ratio, and the liquidity have been less studied (See for example Saeedi and Mahmoodi (2013), Alipour et al. (2015).

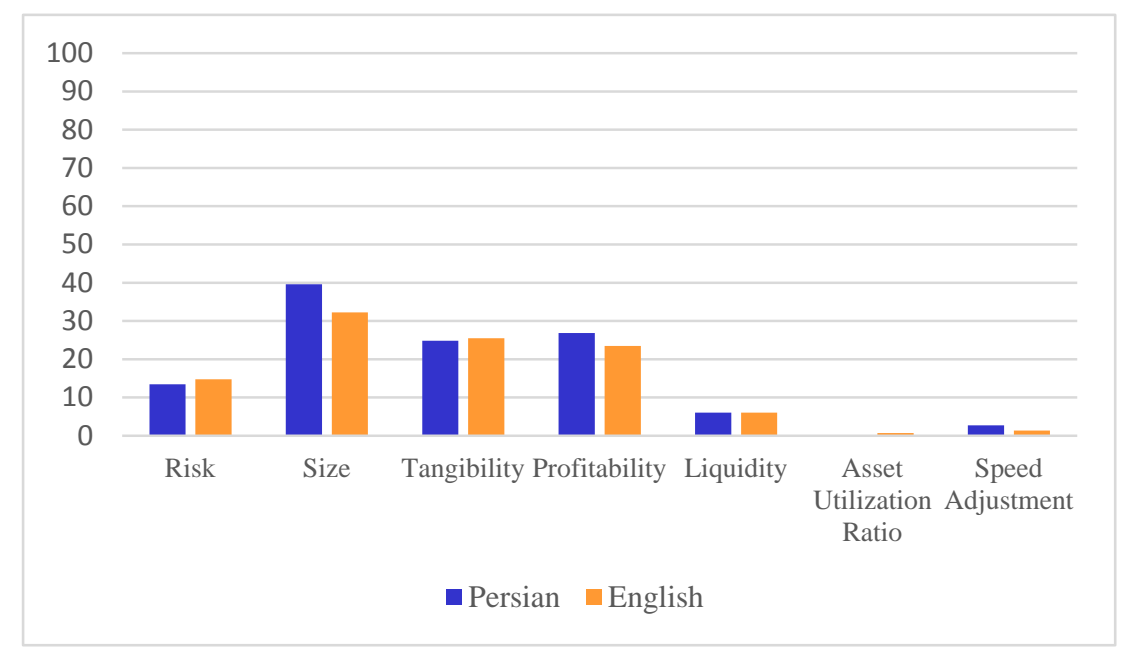

Figure 1. Frequency of variables used in researches related to capital structure in Iran

These two ratios can be significant affect the capital structure decisions in developing countries. In other words, in most of these countries, the problem of liquidity becomes apparent when companies want to increase their assets. The first step, to solve a part of the problem of the company's lack of capital is the optimal use of existing assets. For example, companies should check whether they can use existing machines instead of purchasing new tools or, if they have unused assets, they can sell out these assets to reduce the need for external financing.

In another part of the research, it is planned to examine the speed of adjustment of corporate capital structure. The concept of the speed of adjustment is rooted in dynamic trade-off theory (Ghose, 2017). Huang and Ritter (2009) states that the company adjustment speed to target leverage is an essential issue in capital structure research. Most studies have looked at the speed of adjustment based on the corporate capital structure of developed countries, while the speed of adjustment rate in developing countries has recently attracted the attention of researchers (Supra, 2016).For this purpose, the speed of adjustment of capital structure for the developing country of Iran is compared with the developed country of Australia. Also in order to estimate the speed rate, In addition to the OLS method, the GMM method which is a robust and valid method for heterogeneity of data And endogenous problems has been used (Lema and Negash, 2014; Oino and Ukaegbu, 2015).

\section{Corporate Financing in Iran and Australia}

\subsection{Iran}

Iranian financial system is bank-oriented, and Commercial Bank has a significant role in the capital market. The following figure shows the ratio of bank credit to the private sector as a percentage of GDP and stock market capitalization as a percentage of GDP. For the ratios greater than one banking sector dominants the system and if it is less than one, the stock market is a major source of financing (Supra et al., 2016). 


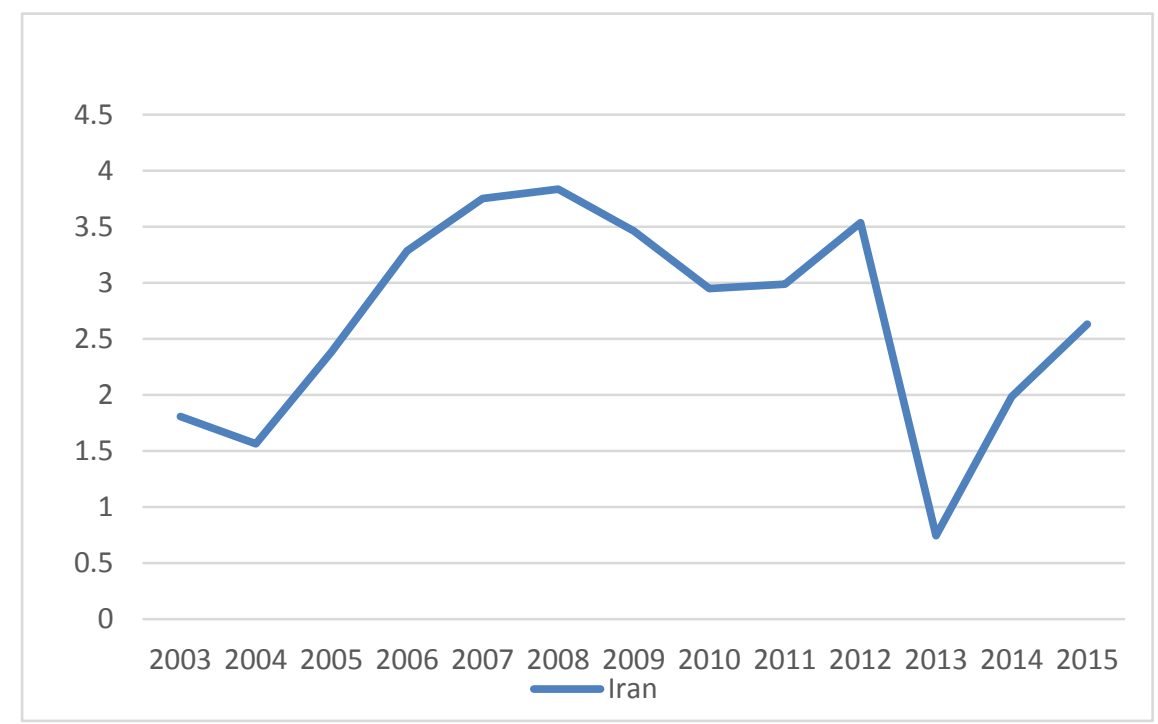

Figure 2. Ratio of the bank credit to market capitalization of Iran (Source: World Bank)

As shown in Figure 2, it is clear that from 2003 to 2012, the banking sector has been dominant in the financial system of Iran. However, one of the developments that took place in the Iranian capital market, especially in 2013, was the unprecedented flourishing of the Iranian stock exchange. According to the statistics and information of Bloomberg, Iranian stock exchange in this year has recorded 132\% return and has been ranked first in the WFE (Minister of Economic Affairs and Finance, 2013), although this trend has not continued over the next few years. Experts have argued that the high cost of financing through Equity (such as the issue of shares) in Iran has reduced the willingness of companies to use this method; At the present time, deposit interest rate of Iranian banks is $15 \%$ which is one of the highest rates among 138 countries (Deposit, 2017). Therefore shareholders are not willing to invest in an institution whose rate of return is less than $25 \%$. This behavior of the shareholders can be interpreted that companies must pay at least 25\% interest to their shareholders (Organization Exchange Security of Iran, 2013). On the other hand, the mechanisms for issuing bonds are not well organized in Iran. According to Iranian legal rules, bonds under the framework of the bank without usury which is based on interest-free borrowing are traded on the market, which creates some ambiguity in financing companies through long-term debt (Jahankhani, 1994).

\subsection{Australia}

Australia companies are active in the financial market and control-free market. An attribute that makes this financial market unique is that, prior to 1987, the Australian financial system was based on a double tax, like the United States, according to which, in addition to taxing the company's income, a tax was levied on the income received by the shareholder's dividends. This raised the incentive for companies to use the advantage of tax shield. (Qiu and La, 2010). However, after 1987, with the implementation of the tax imputation system, Australian shareholders receive the full credits of the tax paid at the corporate level when they receive dividends (Qiu and La, 2010). Thus, the elimination of double taxation has led to a reduction in the incentive to use debt as a form of corporate financing. Australian banks are among the most profitable banks in the world. Banking in Australia is dominated by a group of large banks known as the "Big Four," which includes ANZ, West Pac, CBA and NAB banks. The capital market of these four banks in comparison with the world's banks is shown in the Figure below. 


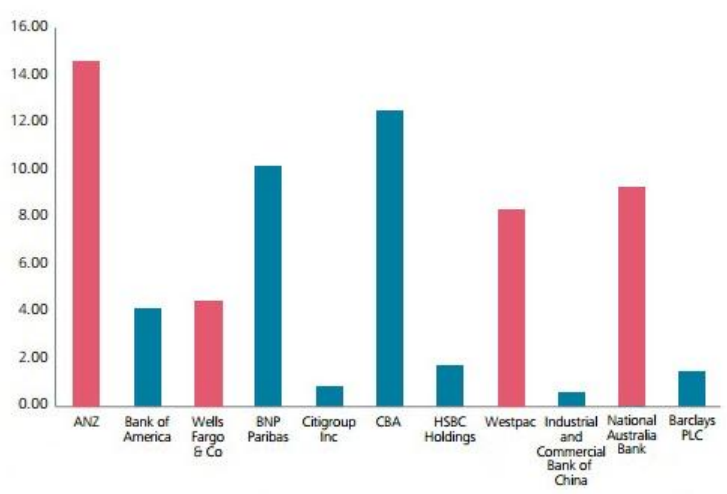

Figure 3. Global market capitalization per customer (Source: Equitise, 2015)

The debt composition of 200 companies in Australian Stock Exchange in figure 4 suggests that most corporate financing takes the form of the loans reflecting the dominance of the Australian banks as a supplier of funding. Also, the loans tend to be used to complete funding requirement between 3 and five years (Equitise, 2015).

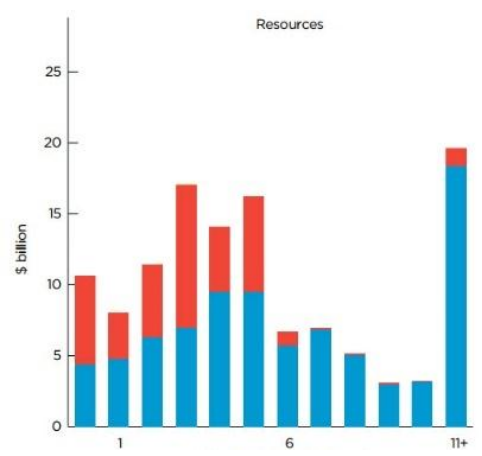

Figure 4. ASX 200 Companies debt composition (Source: Bloomberg RBA)

\section{Main Connections with the Literature}

Much research has been done since the publication of the theory of Modigliani and Miller (1958a), in which, under specific assumptions, the value of a company is independent of its capital structure. However, this theory was unable to explain the empirical findings of the capital structure in the real world. These efforts created other fundamental theories, such as Trade-off theory, Pecking Order theory in determining the composition of capital structure (Chen, 2004 and Afshari Maneh, 2015). The focus of all these theories is the impact of the type of financing source on the value of the company (Miglo, 2016). The following describes each of these theories.

\subsection{Trade-off Theory}

Based on the second M\&M proposition, corporate financing should be fully funded through the debt method because of tax saving from debt. This is while practical results show at many times, companies prefer debt financing. In justifying this behavior, Kraus and Litzenberger (1973) presented statistic trade-off theory states that increasing the weight of debt in the capital structure, increases the risk of bankruptcy resulting from the company's inability to repay annual interest and principal payments on the debt. In other words, companies that use the trade-off theory model will consider the target leverage and adjust the company's direction to it. He believes that this proportion of the target leverage is made by creating a balance between the benefits of the debt tax shield and the cost of bankruptcy due to the probability that the company will fail to comply promptly (Izadinia and Rasaiian, 2009). Hence, the two neutralizers marginal benefit and marginal cost lead to the optimal use of debt in the capital structure. Within the framework of this theory, companies try to balance the benefits of saving tax on debt and bankruptcy costs to create the highest corporate value (Brealey et al., 2010).

In contrast, Fischer et al. (1989) have shown Dynamic trade-off theory. Based on this model, companies have a partial adjustment to optimal leverage due to existing adjustment costs (Serrasqueiro and Caentano, 2014).In another 
word, due to the activity of the companies in-the Imperfect capital market, companies temporarily diverge from target leverage. However, the restructuring of capital structure (such as issue and repurchase debt) is costly. Therefore, Firms whose leverage ratio do not coincide with their target leverage will only adjust capital structure when the benefit of adjusting to being higher than cost (Dudley, 2007). The importance of this theory is for two reasons; First, in contrast to static trade-off theory, which states that each company has one optimal leverage, in which the value of the company is optimized. Dynamic trade-off theory expresses companies consider a range of target leverage and allow their debt ratios to change in this optimal range (Ehrhardt and Brigham, 2017). Second, the moderation rate towards optimal leverage depends on the benefit of adjustment and cost adjustment (Flannery and Rangan, 2006). Therefore, adjustment speed of the corporations differs under the influence of adjustment costs and corporate features. (Sheri Anaqiz et al., 2015). Hence, the researchers argued that the adjustment costs would prevent companies from moving forward towards the leverage (Fakhrhosseini and Sangdovini, 2016).

\subsection{Pecking Order Theory (POT)}

The root of the pecking order theory should be sought in Myers (1984). According to the POT theory, companies, regardless of the level of optimal leverage, will finance only based on a predetermined hierarchy. This hierarchy is the result of asymmetric information between individuals inside and outside the organization, which leads to an adverse selection of choices between executives and external investors (Laskin, 2012). In other words, one of the consequences of asymmetric information will be an adverse selection of investors. In this case, investors have less information about the company's actual value than those inside the organization. As a result, the POT states that the financing of the company is based on the investor's reverse selection problem; that is, financing start from the company's internal resources, which has no adverse selection problem and creates the lowest financing cost for the company. Then, if internal resources are not sufficient, among the external sources, debt is preferred to stock. Also among the methods of debt financing, companies use short-term debt (such as a bank loan) before long-term debt, and among the long-term debt methods, guaranteed securities, such as corporate bonds is preferred. Ultimately, if none of the resources for financing the company is sufficient, as a last resort, the company will fund through equity (such as stocks), in which the problem of adverse selection will reach to the highest point, and from the perspective of investors, the risk is high (Baker and Martin, 2011).

\section{Determinants of Capital Structure}

The study follows the framework put forth by Rajan and Zingales (1995) and uses four factors including Tangibility (FA), Firm Size (SIZE), Profitability (PROF) and Business Risk (RISK), as core explanatory variables. The core above factors have been used in the majority of previous studies as potential instrumental factors in determining capital structure in research models (e.g., Sakatan (2010), Koksal and Orman (2014), Serrasqueiro and Caetano (2015). Additionally, the Asset Utilization Ratio (AUR) and Liquidity (LIQ) were used as a subsidiary variable in the research model (Alipour et al., 2015). Therefore, the general form of the model can be specified as follows:

$$
D R=f(F A, \text { SIZE, PROF, RISK, LIQ, AUR })
$$

\subsection{Measures of Leverage}

It is necessary to define what exactly is meant by leverage before any empirical capital structure test. There are different forms of debt, equity, and the combination of these two and therefore, there is no universally accepted definition of leverage in the literature. (Lema and Negash, 2014). Empirical studies demonstrate that different measures of leverage may show mixed results, which affect the interpretation of capital structure determinants (Harris and Raviv, 1991). Rajan and Zingales (1995) have applied four alternative definitions of leverage. The first and broadest definition of leverage is the total debt ratio (total liability to total assets), which can be viewed as the percentage of firm's assets that are financed with debt (sum of long term and short term debt).The second definition is the long-term debt (the ratio of long-term debt to the total asset), this measurement represents the percentage of corporate assets financed with debts and financial obligations lasting over one year. The borrower obligated to payback principle (amount borrowed) as well as interest (a percentage rate representing the price for borrowing) (Caprio and Demirguc-Kunt, 1996). The third definition is the short-term debt (the ratio of short debt to total assets); this measure of leverage only covers short-term bank loans. The fourth definition pertains to the importance of distinguishing between book leverage (debt divided by total assets) and market leverage (book debt divided by the sum of the book debt plus the market equity).The fundamental difference between book and market leverage is that companies can actively manage the behavior of the book leverage, while market leverage is determined primarily by market force (Adrian et al., 2016). According to the above explanation, the present study used the two total debt ratio (TD) and long-term debt ratio (LD) indices to measure the book leverage. 


\subsection{Tangibility}

Tangibility is one of the most relevant variables in corporate finance decisions (Koksal and Orman, 2014). Most studies have reported a positive relationship between tangibility and leverage ratio, which supports the TOT (Koksal and Orman, 2014). To provide examples of studies conducted in this connection, Ting and Chin (2016) investigated the factors affecting the capital structure of 54 textile manufacturing companies in Pakistan. The results demonstrated a positive relationship between long-term debt and tangible assets, which is because fixed assets have a collateral value and can be used by firms as back-up for annual interest and principal payments on the debt. This relationship is in line with the studies conducted by Koksal and Orman (2014) and Ahmad and Muhtar (2017), which reported a positive correlation between tangibility and leverage ratio.

A few number of studies have reported a negative relationship between tangibility and leverage ratio, which supports the POT (Koksal and Orman, 2014). Serrasqueiro (2014) investigated the factors affecting SMEs in different regions of Portugal. The results demonstrated a negative relationship between tangibility and leverage, which is because companies with high fixed assets prefer to use internal resources with no information asymmetry problem. This is consistent with the studies by Li and Stathis (2017) and Daskalakis and Psillaki (2008), which reported a negative relationship between tangibility and leverage ratio. Finally, in the study conducted by Sakatan (2010), which included non-financial companies in Saudi Arabia, there was no significant relationship between tangibility and leverage ratio during the period 1988-2007. Based on the discussion above, the first hypothesis was formulated.

$\mathrm{H}_{1}$ : Tangibility affects leverage ratios.

\subsection{Firm Size}

Firm size is another firm level factor used in research to investigate the factors affecting capital structure. Most studies have reported a positive relationship between firm size and leverage ratio, which supports the TOT (Tugba, 2012). Zerriaa and Noubbigh (2015) investigated the factors affecting the capital structure in 32 non-financial firms on the Tunisian stock exchange, demonstrating that firm size has a positive relationship with leverage ratio. This result is in line with the results of Ahmad and Muhtar (2017), Kopyakova (2017), and Balios et al. (2016). Large corporations are usually maturing, with high fixed assets, profitability, and financial flexibility. Usually, these companies in the debt market have credibility and reputation and have better access to capital markets. On the other hand, large corporations have lower fluctuation in cash flow, which leads to lowers the risk of bankruptcy in these companies. (Koksal and Orman, 2014). They also have a bargaining power when using debt, compared to smaller ones, and can reduce the costs associated with the issuance of long-term debt (Kordestani and Najafi, 2009). Hence, TOT predicts a positive relationship between company size and leverage ratio.

A few number of studies have reported a negative relationship between firm size and leverage levels, a relationship which supports the POT (Tugba, 2012). For example, Alipour et al. (2015) demonstrated that the firm size of non-financial firms on the Iranian stock exchange has a negative relationship with the long-term and short-term debt ratios. This result is consistent with the results obtained by Rajagopal (2011) and Tan-Kah-Keng et al. (2016). The POT predicts the relationship between firm size and leverage ratio negatively. The reason is that large corporations, as compared to small businesses, disclose more information for external investors (Rajan and Zingales, 1995). Therefore large companies have lower information asymmetry between managers and outsiders that make equity as a desirable source of funding. (Huang and Song 2006). Based on the discussion above, the second hypothesis was formulated.

$\mathrm{H}_{2}$ : Firm size affects leverage ratios.

\subsection{Profitability}

Profitability is one of the variables examined as a factor affecting the capital structure in most studies. The reason for the importance of profitability is the fact that firms can use it as a source of financing (Tugba, 2012). Fama and French (2002) demonstrated a negative correlation between profitability and leverage levels. The reason of this relation is that profitable companies are likely to have high available retained earnings so that they may not have severe internal financial. Therefore profitable businesses tend to use their internal resources which contain no adverse selection problems. This relationship is in line with the results of Abdeljawad and Mat Nor (2017) study and Abdul Hadi et al. (2016) which both supports the POT .

Some other studies have demonstrated a positive relationship between profitability and firm leverage levels that support static trade off theory. For example, Rajan and Zingales (1995) showed that increased profitability provides the firms with sufficient internal funds to repay their debt obligations. The reason for this relation is that the profitable companies have retained earnings and high internal funds for repayment of debt obligations. Therefore, 
they are likely to use more debt to finance to reduce the cost of financing by increasing tax savings from debt. Savings tax on debt can be used to finance corporate projects and increase the value of the company. This is consistent with the study conducted by Zerriaa and Noubbigh (2015).

Furthermore, the results obtained by Kayhan and Titman (2007) are consistent with the dynamic trade-off theory, which maintains that firms whose leverage ratio do not coincide with their target leverage will only adjust capital structure when the benefit of improving to being higher than cost (Dudley, 2007). Profitable companies are likely to have high available retained earnings so that they may not have severe internal financial. Therefore, profitable companies do not regularly change leverage ratios due to cost adjustments such as transaction costs. (Koksal and Orman, 2014; Tugba, 2012; Valipour et al. 2011; Frank and Goyal 2009c).

Most studies have revealed a negative relationship between profitability and leverage ratio (see for example, Kopyakova, 2017; Abdul Hadi et al., 2016; Ukaegbu and Oino, 2013) which supports the POT and Dynamic trade-off theory. Based on the discussion above, the third hypothesis was formulated.

$\mathrm{H}_{3}$ : Profitability affects leverage ratios.

\subsection{Liquidity}

Another variable influencing capital structure is liquidity (Taleb, 2015). The results of the previous studies have reported mix correlations between liquidity and leverage ratio. For example, Pacheco (2015) investigated the factors influencing the capital structure of Portugal firms from 2011 to 2014. He finds a negative relationship between liquidity and leverage ratio, which is because companies with stable cash are more willing to use internal resources; this association supports the POT theory. It is also consistent with the results obtained by Imtiaz et al. (2016) and Ting and Chin (2017), which demonstrated a negative relationship between liquidity and leverage ratio of firms.

Furthermore, some other studies have reported a positive relationship between liquidity and leverage ratios. For example, Belkhir et al. (2015) investigated 444 firms from 10 countries in the MENA region during 2003-2011. They demonstrated a positive relationship between liquidity and leverage ratio, which is because companies with high liquidity have a higher potential for repaying debt-financing liabilities, which reduces bankruptcy costs for these companies. As a result, these companies have a more significant tendency towards debt-financing to reduce their financing cost by increasing debt-tax savings. This relationship supports the TOT theory and is in line with the studies conducted by Babu and Chalam (2016) and Wolters (2017). In the light of the preceding discussion, forth hypothesis is formulated.

$\mathrm{H}_{4}$ : Liquidity affects leverage ratios.

\subsection{Asset Utilization Ratio}

This ratio measures the efficiency of assets in generating sales. In other words, it provides information as to how efficiently the firm is using its assets to generate revenue and cash flow. The higher the asset utilization ratio, the better performance of the company to generate a more revenue per dollar of assets (Risius, 2007). The results of the previous studies have reported mix relationships between leverage and asset utilization ratio. For example, Feidakis and Rovolis (2007) investigated the factors affecting the capital structure of the listed European construction companies over the years 1996-2004, demonstrating a negative relationship between total debt and asset utilization in long-term debt. In other words, as the companies' efficiency increases, equity is used more than debt for financing. One reason to explain this relationship is that the increased efficiency of companies in using fixed assets for sale leads to the increased potential of the corporate to generate cash flow, which reduces the companies' need to finance outside the company (Alipour et al., 2015).

Another group of studies has reported a positive relationship between leverage and asset utilization ratio. For instance, Volugaris et al. (2007) investigated the factors affecting the capital structure of Greek manufacturing companies. For this purpose, two samples of large and small firms were used. The results demonstrated that, in large companies, there is a positive relationship between asset utilization ratio and the leverage ratio of the company, while there is no significant relationship between the two factors in small businesses. This is in line with the results obtained by Filbeck and Gorman (2000) and Alipour et al. (2015). Considering the above explanation, fifth hypothesis is formulated.

$\mathrm{H}_{5}$ : Asset utilization ratio affects leverage ratios.

\subsection{Business Risk}

Business risk is one of the significant factors affecting a company's capital structure (Johnson and Soenen, 2003). It is an uncertainty arising from the difference between actual returns and the company's expected returns due to 
fluctuations in the company's earnings (Minton and Schrand, 1999). Most studies have reported a negative relationship between business risk and a corporate leverage ratio (Ukaegbu and Oino, 2013). For instance, Kopyakova (2017) examined the factors affecting the capital structure in the two groups of firms listed and those not listed on the German stock exchange. The results demonstrated a negative relationship between business risk and leverage ratio, which is consistent with the TOT and POT. This result is in line with those obtained by Alipour et al. (2015), Rajagopal (2011), and Sakatan (2010). According to the TOT, high-risk firms experience increased debt-financing costs; hence, companies do not have a high tendency towards using debts. In other words, high fluctuation in the firm's revenue increases the likelihood of the firm's failure to meet its obligation, which could lead to prosecution against the company by the creditors. Hence, creditors, who expect their capital to be secured in the company, seek more stringent conditions to offset the risk, which causes higher debt-financing cost for the firm. Similarly, according to the POT, Also, based on the POT model, for companies with high earnings volatility, the risk of the inability of the company to repay annual interest and principal payments on debt is more considerable. Therefore in this situation; corporations change their financing hierarchy to use internal and equity funding resources instead of debt. (Koksal and Orman 2014, Zou and Xiao 2006). In the light of the preceding discussion, the sixth hypothesis formulated.

$\mathrm{H}_{6}$ : Business risk affects leverage ratios.

\subsection{Speed of Adjustment}

The concept of adjustment speed is rooted in the dynamic trade-off theory (Ghose, 2017), It states that companies, due to their activities in an imperfect capital market deviate from the target leverage temporarily (Supra et al., 2016). However, adjustment costs, such as transaction costs, make companies unable to quickly offset the target leverage (Serrosquiro and Caetano, 2015). Therefore, when a company deviates from the target leverage, it has four options. If the company is over the leverage, the managers can return to the target leverage by issuing new equity or retiring the debt, and when the company is under the leverage, the managers can repurchase shares or issue new debt to take advantage of the tax shield (Oino and Ukaegbu, 2015). Nerveless, since all these methods are costly, firms adjust the leverage level to the optimal leverage at different speeds due to their different characteristics (Ghose, 2017). The rate of adjustment has been widely analyzed in developed countries, while there is limited research in the emerging market. Getzmann and Lang's study (2010) determine the adjustment speed for developed countries. Their result shows that the capital adjustment speed for the Americas, Europe, and Asia has been estimated in the period 1995 to 2009. The results, via the GMM, showed that the average adjustment speed is $46 \%$ for the Americas, $56 \%$ for Europe, and $31 \%$ for Asia. In another study by Wanzenried (2007), the adjustment speed for France, UK, and Germany in the period between 1988 and 2002 was estimated at 23\%, 11\%, and 19\% respectively. However, fewer studies have estimated the adjustment speed in developing countries. One of these studies is Lema and Negash (2014), in which the adjustment speed for nine African countries was estimated to be $39.4 \%$ by Sys GMM Panel data from 1999 to 2008. The study argued that the high adjustment speed be due to the rapid growth in these nine countries. Haas and Peeters (2006) calculated the adjustment speed for Eastern European countries from 1996 to 2001, demonstrating the following adjustment speed: Bulgaria, Czech Republic and Estonia 16\%, Latvia 14\%, Hungary 13\%, Lithuania 12\%, Poland $11 \%$, and Slovenia, Romania and Slovakia 7\%. The difference in the adjustment speed of this hypothesis is reinforced by the fact that the benefits or costs of restructuring the capital structure vary according to corporate characteristics. In other words, companies which deem the benefits of capital structure adjustment more than the cost of adjustment are more likely to have a faster speed, and those who consider the cost of adaptation more than the benefits have a slower rate (Lema and Negash, 2014). Therefore, this study intends to compare the capital structure adjustment speed in Iran with that in Australia. According to the explanation provided, hypothesis 7 was formulated;

$\mathrm{H}_{7}$ : There is an adjustment speed of capital structure for both Iranian and Australian companies.

In following table outlines, the methods of measurement of research variables have been summarizing. 
Table 1. Outlines the methods of measurement of research variables

\begin{tabular}{|c|c|c|c|c|}
\hline Symbol & Factor & Definition & Calculation formula & Resource \\
\hline $\mathrm{TD}_{\mathrm{it}}$ & Total Debt & $\begin{array}{l}\text { The ratio of total debt for } \\
\text { company } i \text { in year } t\end{array}$ & Total debt/Total assets & Matemilola et al. (2013) \\
\hline $\mathbf{L D}_{\mathrm{it}}$ & Long-term Debt & $\begin{array}{l}\text { The ratio of long-term debt } \\
\text { for company } i \text { in year } t\end{array}$ & $\begin{array}{l}\text { Long-term debt/Total } \\
\text { assets }\end{array}$ & Matemilola et al. (2013) \\
\hline $\mathbf{F A}_{\text {it }}$ & Tangible Asset & $\begin{array}{c}\text { Fixed assets for company i } \\
\text { in year } t\end{array}$ & Fixed assets/Total assets & Matemilola et al. (2013) \\
\hline PROF $_{\text {it }}$ & Profitability & $\begin{array}{l}\text { Profitability for company } \mathrm{i} \\
\text { in year } \mathrm{t}\end{array}$ & Net profit/Total assets & Matemilola et al. (2013) \\
\hline $\mathbf{L I Q}_{\text {it }}$ & Liquidity & $\begin{array}{l}\text { Liquidity for company } \mathrm{i} \text { in } \\
\text { year } \mathrm{t}\end{array}$ & $\begin{array}{l}\text { Current assets-Current } \\
\text { liability/Total assets }\end{array}$ & Alipour et al. (2015) \\
\hline $\operatorname{SIZE}_{i \mathrm{t}} \mathrm{t}$ & Firm Size & Firms size $\mathrm{i}$ in year $\mathrm{t}$ & Log (total asset) & Li et al. (2017) \\
\hline $\mathbf{A U R}_{\text {it }}$ & $\begin{array}{l}\text { Asset utilization } \\
\text { ratio }\end{array}$ & $\begin{array}{l}\text { Asset utilization ratio for } \\
\text { company } i \text { in year } t\end{array}$ & Sales/total assets & Alipouret al (2015) \\
\hline RISK $_{\text {it }}$ & Risk & Risk for company $\mathrm{i}$ in year $\mathrm{t}$ & $\begin{array}{l}\text { Standard deviation of } \\
\text { EBIT/Total assets }\end{array}$ & $\begin{array}{c}\text { Zarebski and } \\
\text { Demovski(2012) }\end{array}$ \\
\hline
\end{tabular}

\section{Empirical Model}

Based on the first objective of the research, we intend to identify the determinants of the capital structure for both Iran Stock Exchange and Australian Stock Exchange. Considering the variables and their computation procedure, the models used in this study are defined as follows:

$$
\begin{aligned}
& L D_{i t}=\alpha_{1}+\alpha_{2} F A_{i t}+\alpha_{3} \operatorname{Prof}_{i t}+\alpha_{4} \text { Liq }_{i t}+\alpha_{5} \text { Size }_{i t}+\alpha_{6} \text { Aur }_{i t}+\alpha_{7} \text { Risk }_{i t}+\mu_{i t} \\
& T D_{i t}=\alpha_{1}+\alpha_{2} F A_{i t}+\alpha_{3} \text { Prof }_{i t}+\alpha_{4} \text { Liq }_{i t}+\alpha_{5} \text { Size }_{i t}+\alpha_{6} \text { Aur }_{i t}+\alpha_{7} \text { Risk }_{i t}+\mu_{i t}
\end{aligned}
$$

In this step, all variables are screened, and the variables with a significant relationship with the capital structure indices are selected. For this purpose, attempts are made to choose a model which includes the best and most efficient variables.

The second objective of the study is to investigate the capital structure adjustment speed in Iranian and Australian listed firms. As mentioned previously, in a perfect market, companies can continuously maintain their capital structure in an optimal condition. In contrast, in an imperfect market, companies face adjustment costs, which will prevent them from rapidly reversing the deviation from target leverage. The model used to estimate the adjustment speed is a partial adjustment model proposed by Marc Nerlove. The partial modulation model can be represented as follows (Gujarati, 2002):

$$
L D_{i, t}-L D_{i, t-1}=\lambda\left(L D_{i, t}^{*}-L D_{i, t-1}\right)+\mu_{i, t}
$$

$D_{i, t+1}^{*}:$ Firm i's desired debt ratio at time $\mathrm{t}$

In fact, this model allows the ith firm to reduce the gap between its real leverage and target leverage by $\lambda$ value each year. If the model is sorted according to the firm's actual leverage, the following value is obtained:

$$
L D_{i, t}=\lambda L D_{i, t}^{*}+(1-\lambda) L D_{i, t-1}+\mu_{i, t}
$$

There are two major obstacles to the estimation of the above model. The first problem is the invisibility or immeasurability of the target leverage $L D_{i, t}^{*}$, and the second is the presence of a lagged dependent variable $L D_{i, t-1}$ among the explanatory variables. To solve the first problem, a reasonable estimate of the target leverage is made using the variables affecting capital structure, and the lagged variable $L D_{i, t-1}$ is measured using Ordinary Least Square (OLS). In order to ensure the robustness of the findings, the results are compared with the Generalized Method of Moments (GMM) (Oino and Ukaegbu, 2015). This model is based on the fact that the target leverage of different companies can be changed over time under the influence of the determinants of the capital structure. Therefore:

$$
L D_{i, t}^{*}=\alpha X_{i, t-1}
$$


According to the trade-off theory, $\alpha \neq 0$. Vector $X_{i, t-1}$ includes a set of factors affecting the capital structure of companies.

Substitution of Equation 6 into Eq. 4 yields the following equation:

$$
L D_{i, t+1}-L D_{i, t}=\lambda\left(\alpha X_{i, t}-L D_{i, t}\right)+\mu_{i, t+1}
$$

Moreover, further substitution yields the following result: (Note 1)

$$
L D_{i, t+1}=\lambda \alpha X_{i, t}+(1-\lambda) L D_{i, t}+\mu_{i, t+1}
$$

Additionally, $X_{i, t}$ refers to the research variable mentioned in the last section. By substituting these variables into Equation 8, the final model for investigating adjustment speed is developed as:

$$
L D_{i t}=\alpha_{1} F A_{i t}+\alpha_{2} \text { Prof }_{i t}+\alpha_{3} L i q_{i t}+\alpha_{4} \text { Size }_{i t}+\alpha_{5} \text { Aur }_{i t}+\alpha_{6} \text { Risk }_{i t}+(1-\lambda) L D_{i, t-1}+\mu_{i t}
$$

Moreover, the total debt ratio model is expressed as:

$$
T D_{i t}=\alpha_{1} F A_{i t}+\alpha_{2} \text { Prof }_{i t}+\alpha_{3} \text { Liq }_{i t}+\alpha_{4} \text { Size }_{i t}+\alpha_{5} \text { Aur }_{i t}+\alpha_{6} \text { Risk }_{i t}+(1-\lambda) T D_{i, t-1}+\mu_{i t}
$$

The $(1-\lambda)$ value ranges between ' 0 ' and ' 1 '; ' 0 ' indicates that the firm has had no capital structure adjustment, and ' 1 ' denotes that the firm has fully adjusted its capital structure and that the capital structure is in optimal condition (Supra et al., 2016). In other words, companies need to optimize their capital structure to maximize the company value. However, in an imperfect capital market, companies diverge from target leverage. To reverse this deviation from the target leverage, the debt or equity must be increased or decreased, which will cost the company. The adjustment costs cause companies to move towards optimal leverage at $\lambda$ speed, which is known as the speed of adjustment. Hence, by subtracting the coefficient estimated for $L D_{\mathrm{i}, \mathrm{t}-1}$ and $T D_{\mathrm{i}, \mathrm{t}-1}$ from ' 1 ', the capital structure adjustment speed is determined (Gorji and Ra'ee, 2015).

$$
1-(1-\lambda)=\lambda
$$

\section{Results}

\subsection{Descriptive Statistics}

Table 2 shows whether the mean value of leverage ratios (TD, LD) is significantly different for the country of Iran and Australia. The two-sample t-test (Snedecor and Cochran, 1989) is used to determine if two population means are different. In this test, the zero assumption shows the difference between the average leverage ratios and the opposite assumption shows the existence of the same mean.

$H_{0}$ : The mean values of leverage ratios (TD, LD) are different between Iran and Australia.

$H_{1}$ : The mean values of leverage ratios (TD, LD) are identical in Iran and Australia.

Table 2. Comparing firm leverage indices (LD and TD) between Iran and Australia

\begin{tabular}{ccccccccc}
\hline & \multicolumn{2}{c}{ Total debt ratio } & \multicolumn{2}{c}{ T-Test for difference } & \multicolumn{2}{c}{ Long-term debt ratio } & \multicolumn{2}{c}{ T-Test for difference } \\
\cline { 2 - 8 } & Iran & Australia & Test statistic & Sig & Iran & Australia & Test statistic & Sig \\
\hline Mean & 0.68 & 0.54 & 2.566 & 0.01 & 0.09 & 0.18 & -9.021 & 0.000 \\
Median & 0.62 & 0.43 & & & 0.05 & 0.13 & & \\
Max & 26.71 & 55.37 & & & 7.59 & 3.1 & & \\
Min & 0.01 & 0 & & 0 & 0 & \\
Std. Dev. & 1.02 & 1.64 & & & 0.25 & 0.23 & \\
Obs. & 1246 & 1309 & & & 1246 & 1309 & & \\
\hline
\end{tabular}

Based on the information presented in table 2, the average ratio of total debt and long-term debt ratio for Iran and Australia is significantly different. Hence, factors affecting capital structure based on corporate characteristics are referred to, which shows the reason for this difference. Based on the average values of the variables, it can be said that the use of debt in the Iranian companies has been more than the Australian firms. As shown in the tables, the average of TD is 0.68 for the Iranian and 0.54 for the Australian companies. These results are in line with the results of Alipour et al. (2015) and Li et al. (2017) where they report the value of TD to be 0.72 and 0.24 for the Iranian and Australian companies respectively. As shown in the table, the value of LD is 0.09 for the Iranian and 0.18 for the Australian companies. The reason that most Iranian corporations tend to use short-term debt is that the mechanisms for issuing bonds are not well organized in Iran. On the other hand, according to the Islamic laws in Iran, bonds are 
released under the non-interest banking system that is based on an interest-free loan that decreases the intensity of the Iranian companies to use debt. This result is in line with the results of Alipour et al. (2015) where the value of LD has been reported to be 0.11 for the Iranian companies and the results of Li et al. (2017) where this amount has been calculated to be 0.17 for the Australian companies.

\subsection{Stationary Test of the Variables}

Before estimating the model and testing the hypotheses, it is necessary to perform the stationary test and calculate unit root test to ensure the results and non-falsity of the existing regression relationships. Accordingly, the results of a stationary analysis of variables based on Levin, Lin, and the Chu are presented in table 3.

Table 3. Unit root test

\begin{tabular}{lccc}
\hline \multicolumn{1}{c}{ Variable } & Stock & \multicolumn{2}{c}{ Levin, Lin \& Chu t } \\
& Exchange & Statistic & Significance Level \\
\hline \multirow{2}{*}{ Total Debt (TD) } & Iran & -305.7 & 0.000 \\
& Australia & -28.28 & 0.000 \\
Long Term Debt (LD) & Iran & -180.87 & 0.000 \\
& Australia & -18.98 & 0.000 \\
Tangibility (FA) & Iran & -311.93 & 0.000 \\
& Australia & -1741.13 & 0.000 \\
Size (SIZE) & Iran & -49.15 & 0.000 \\
Profitability (PROF) & Australia & -81.41 & 0.000 \\
& Iran & -17.78 & 0.000 \\
Liquidity(LIQ) & Australia & -37.12 & 0.000 \\
& Iran & -10593.7 & 0.000 \\
Asset utilization ratio (AUR) & Australia & -151.1 & 0.000 \\
& Iran & -161.37 & 0.000 \\
Risk (RISK) & Australia & -41.8 & 0.000 \\
& Iran & -142.13 & 0.000 \\
& Australia & -583.35 & 0.000
\end{tabular}

In the Levin, Lin and Chu test, the null hypothesis implies the existence of unit root and the alternative hypothesis suggests the absence of unit root. Based on the results of table 3, the significance level of all variables in both Iranian and Australian companies is less than 5\%. Thus, the null hypothesis regarding the existence of unit root is rejected.

\subsection{Kao Residual Cointegration Test}

In this stage, long-term equilibrium relations among the variables are examined. Given the heterogeneity in the residual terms in the panel data, Kao Cointegration test is used. The results of the Kao Cointegration test are shown in table 4.

Table 4. Kao residual cointegration test

\begin{tabular}{|c|c|c|c|}
\hline \multirow{2}{*}{ Stock Exchange } & \multirow{2}{*}{ Set of Variables } & \multicolumn{2}{|c|}{ Augmented Dickey-Fuller (ADF) } \\
\hline & & Statistic & Significance Level \\
\hline \multirow{2}{*}{ Iran } & TD, FA, SIZE, PROF, LIQ, AUR and RISK & -16.14 & 0.000 \\
\hline & LD, FA, SIZE, PROF, LIQ, AUR and RISK & -18.76 & 0.000 \\
\hline \multirow{2}{*}{ Australia } & TD, FA, SIZE, PROF, LIQ, AUR and RISK & -14.68 & 0.000 \\
\hline & LD, FA, SIZE, PROF, LIQ, AUR and RISK & -2.42 & 0.007 \\
\hline
\end{tabular}

As shown in table 4 , the significance level in all states is less than 0.05 , indicating the confirmation of the alternative hypothesis regarding the existence of cointegration among the research variables.

6.4 Comparison of the Factors Affecting Capital Structure in Iran Stock Exchange and Australian Stock Exchange

\subsubsection{F-Limer Test}

To select the best methods of panel data and pool data, F-Limer test is used. The results of this analysis are shown in table 5 . 
Table 5. Results of F Limer test (Chow test)

\begin{tabular}{ccccc}
\hline $\begin{array}{c}\text { Stock } \\
\text { Exchange }\end{array}$ & Independent Variable & F-Statistics & Significance Level & Result \\
\hline \multirow{2}{*}{ Iran } & Total Debt Ratio & 6.86 & 0.000 & Panel data \\
& Long term Debt Ratio & 4.55 & 0.000 & Panel data \\
& Total Debt Ratio & 9.10 & 0.000 & Panel data \\
Australia & Long term Debt Ratio & 4.13 & 0.000 & Panel data \\
& & &
\end{tabular}

In F-Limer test, the null hypothesis represents the pool data, and the alternative hypothesis represents panel data. If the calculated significance level is higher than 0.05, pool data and otherwise panel data are used. The results of table 5 show that in all research models for the Iranian and Australian companies, the significance level is less than 0.05 . Hence, it is concluded that in the estimation of the regression model, panel data should be used.

\subsubsection{The Hausman Test}

After performing the F-Limer test and ensuring that the data is panel data, in the next step it is examined that whether the intercept is as fix effect or random effect. The Hausman test is used to determine the fix or random effects in panel data.

Table 6. Housman test results

\begin{tabular}{ccccc}
\hline $\begin{array}{c}\text { Stock } \\
\text { Exchange }\end{array}$ & Independent Variable & F-Statistics & Significance Level & Results \\
\hline \multirow{2}{*}{ Iran } & Total Debt Ratio & 311.91 & 0.000 & Fix effects \\
& Long term Debt Ratio & 100.26 & 0.000 & Fix effects \\
Australia & Total Debt Ratio & 5.39 & 0.494 & Random effects \\
& Long-term Debt Ratio & 6.64 & 0.355 & Random effects \\
\hline
\end{tabular}

In the Hausman test, the null hypothesis represents random effects, while the alternative hypothesis represents fix effects. Therefore, the results of the F-Limer and Hausman tests showed that the estimation of the regression models of the Iranian companies is performed based on the panel data-fix effect method while that of the Australian firms is based on panel data-random effects.

\subsubsection{Estimating Multiple Regression Models}

The results of regression analysis for the companies listed in Iran and Australia Stock Exchange are shown in table 7 and 8 .

Table 7. Determinants of the capital structure of the companies listed in Iran stock exchange

\begin{tabular}{|c|c|c|c|c|c|c|}
\hline $\begin{array}{l}\text { Model } \\
\text { Dependent variable } \\
\text { Estimation method }\end{array}$ & \multicolumn{2}{|c|}{$\begin{array}{l}\text { First } \\
\text { Total Debt Ratio (TD) } \\
\text { Fixed Effects }\end{array}$} & & \multicolumn{2}{|c|}{$\begin{array}{l}\text { Second } \\
\text { Long-term Debt Ratio (LD) } \\
\text { Fixed Effects }\end{array}$} & \multirow[b]{2}{*}{$\begin{array}{l}\text { Significant } \\
\text { Level }\end{array}$} \\
\hline Independent variable & Coefficient & t-Statistic & $\begin{array}{l}\text { Significant } \\
\text { Level }\end{array}$ & Coefficient & t-Statistic & \\
\hline $\mathrm{C}$ & 0.644 & 1.70 & 0.08 & 0.146 & 1.373 & 0.170 \\
\hline Tangibility (FA) & 0.526 & 32.974 & 0.000 & 0.203 & 45.319 & 0.000 \\
\hline Size (SIZE) & -0.152 & -2.498 & 0.012 & -0.031 & -1.856 & 0.063 \\
\hline Profitability (PROF) & -1.448 & -11.172 & 0.000 & -0.270 & -7.414 & 0.000 \\
\hline Liquidity(LIQ) & 0.000 & 0.419 & 0.675 & 0.000 & 0.555 & 0.578 \\
\hline $\begin{array}{l}\text { Asset utilization ratio } \\
\text { (AUR) }\end{array}$ & 1.045 & 33.459 & 0.000 & 0.122 & 13.978 & 0.000 \\
\hline Risk (RISK) & -0.154 & -2.785 & 0.005 & -0.019 & -1.247 & 0.212 \\
\hline Adjusted R-square & 0.877 & & & 0.863 & & \\
\hline F-statistic & 42.597 & & & 38.004 & & \\
\hline Sig (F-statistic) & 0.000 & & & 0.000 & & \\
\hline
\end{tabular}


Table 8. Factors affecting the capital structure of companies listed on Australian stock exchange

\begin{tabular}{|c|c|c|c|c|c|c|}
\hline \multirow{2}{*}{$\begin{array}{l}\text { Model } \\
\text { Dependent Variable } \\
\text { Estimating model } \\
\text { Independent variable }\end{array}$} & \multicolumn{2}{|c|}{$\begin{array}{l}\text { Third } \\
\text { Total Debt Ratio (TD) } \\
\text { Random Effects }\end{array}$} & & \multicolumn{2}{|c|}{$\begin{array}{l}\text { Fourth } \\
\text { Long-Term Debt Ratio (LD) } \\
\text { Random Effects }\end{array}$} & \multirow[b]{2}{*}{$\begin{array}{l}\text { Significant } \\
\text { Level }\end{array}$} \\
\hline & Coefficient & t-Statistic & $\begin{array}{l}\text { Significant } \\
\text { Level }\end{array}$ & Coefficient & t-Statistic & \\
\hline $\mathrm{C}$ & 0.485 & 6.243 & 0.000 & 0.094 & 4.054 & 0.000 \\
\hline Tangibility (FA) & 0.000 & 0.707 & 0.479 & 0.000 & -0.301 & 0.763 \\
\hline Size (SIZE) & $0.060-$ & -2.038 & 0.041 & 0.053 & 6.049 & 0.000 \\
\hline Profitability (PROF) & -0.172 & -123.179 & 0.000 & 0.000 & -0.935 & 0.349 \\
\hline Liquidity(LIQ) & 0.000 & -1.482 & 0.138 & 0.000 & -0.330 & 0.741 \\
\hline $\begin{array}{l}\text { Asset utilization ratio } \\
\text { (AUR) }\end{array}$ & 0.158 & 5.220 & 0.000 & -0.027 & -2.509 & 0.012 \\
\hline Risk (RISK) & 0.000 & 0.250 & 0.802 & 0.000 & 0.861 & 0.389 \\
\hline Adjusted R-square & 0.936 & & & 0.038 & & \\
\hline F-statistic & 2741.777 & & & 8.425 & & \\
\hline Sig (F-statistic) & 0.000 & & & 0.000 & & \\
\hline
\end{tabular}

According to the first hypothesis of the research $\left(\mathrm{H}_{1}\right)$, tangible assets have affected both the ratio of total debt and long-term debt ratio as leverage indexes in the Iranian stock market. Based on the estimated regression coefficient, the correlation between tangible assets and leverage ratios are positive. This means that increasing the tangible assets in Iranian companies will increase the ratio of total debt and long-term debt ratio. This result is consistent with the researchers of Koksal and Orman (2014), Ting and Chin (2016), Ahmad and Muhtar (2017). The presence of a positive correlation matches the TOT prediction, which states that companies with more tangible assets, having a higher credit rating, incur a lower debt cost. In other words, a company with a tangible asset has more ability to attract liability since the company has more power in repaying annual interest and principal payments on the debt. Tangible assets are also used as collateral and, in the event of bankruptcy, companies can be able to meet their debt obligations; therefore, companies use tax savings from debt by increasing debt in the capital structure (Koksal and Orman, 2014). Results for the Australian companies show contrary to the first hypothesis of research, the effect of tangible assets on the ratio of total debt and long-term debt ratio was not significant; on this basis, it can be said that changes in the leverage ratio are not affected by tangible assets. This is consistent with the research of Serrasqueiro and Caetano (2014). Therefore, the results show that tangible assets in the developing country of Iran and the developed country of Australia do not equally affect the structure of capital. Considering regression coefficient total debt, by increasing tangible assets, Iranian executives tend to use debt as the primary source of financing. Considering the estimated regression coefficient of leverage ratios (TD, LD), it can be argued that with the increase in the tangible assets, the desire of Iranian managers to use long-term and short-term debt simultaneously increased, but the percentage of using short-term debt is higher than long-term debt. On the other hand, for the developed country of Australia, the increase intangible assets do not change the composition of financing methods.

The results for the Iranian companies have been mixed for the second hypothesis $\left(\mathrm{H}_{2}\right)$. This means that the size of the company has a significant effect on total debt ratio, but the effect of firm size on long-term debt ratio is not significant. Also, according to the estimated regression coefficient of this effect, the total debt ratio is negative, it shows that with the increase in the size of Iranian companies, the ratio of total debt decreases. The existence of a negative correlation between firm size and leverage level is consistent with Alipour et al. (2015), Rajagopal (2011), Tan-Kah-Keng et al. (2016) research. The presence of a negative correlation matches the POT prediction, which states that large companies disclose more information for external investors compared to small companies (Rajan and Zingales, 1995). Therefore, for large companies, the problem of information asymmetry is less between managers and external investors, which leads to increase their willingness to use equity rather than debt (Huang and Song, 2006).

Results for the Australian companies consistent with the second hypothesis $\left(\mathrm{H}_{2}\right)$, firm size affects both the total debt ratio and the long-term debt ratio as the leverage indices of the Australian Stock Exchange. According to the estimated regression coefficient, this effect follows a negative direction for the total debt ratio and a positive direction for the long-term debt ratio, respectively. This is consistent with the study by Sakatan's (2010). Therefore, the results show that the size of the company in the developing country of Iran and the developed country of 
Australia do not equally affect the structure of capital. Considering regression coefficient total debt, by increasing size of the company, Iranian and Australian executives tend to use equity as the primary source of financing. Also, considering the estimated regression coefficient of leverage ratios (TD, LD), it can be argued that among debt financing methods, the desire of Australian executives to use longer-term debt is higher than short-term debt. However, for Iranian companies, the long-term debt ratio is not affected by the size.

According to the third hypothesis $\left(\mathrm{H}_{3}\right)$, profitability on both the ratio of total debt and long-term debt ratio has been affected and regarding the estimated regression coefficient, this effect is negative. This means that increased profitability in Iranian companies reduces the ratio of total debt and long-term debt ratio. This relationship is consistent with the results of Abul Hadi et al. (2016), Kopyakava (2017), Abdeljawad and Mat Nor (2017). The existence of a negative relationship is consistent with the predictions of the Pecking order theory and dynamic trade-off theory. According to the POT, the relationship between profitability and leverage level is predicted as negative, since profitable companies, thanks to their high internal funds, are more inclined to use internal resources (i.e., retained earnings) which are free from the problem of adverse selection caused by information asymmetry. Hence, they have a low tendency towards the use of debt. (Koksal and Orman, 2014; Tugba, 2012). Similarly, the dynamic trade-off theory predicts a negative relationship between profitability and leverage levels. Because firms whose leverage ratio do not coincide with their target leverage will only adjust capital structure when the benefit of improving to being higher than cost (Dudley, 2007). Profitable companies are likely to have high available retained earnings so that they may not have severe internal financial. Therefore, profitable companies do not regularly change leverage ratios due to cost adjustments such as transaction costs. (Koksal \& Orman, 2014; Tugba, 2012; pour et al. 2011; Frank and Goyal 2009c). Also, the negative relationship between Profitability with long-term debt ratio (LD) indicates that the willingness of Iranian companies to use long-term debt has been less. The reason for this is that the mechanisms for issuing bonds are not well organized in Iran. Also, according to Iranian legal rules, bonds under the framework of the bank without usury which is based on interest-free borrowing are traded on the market, which creates some ambiguity in financing companies through long-term debt (Jahankhani, 1994).Results for the Australian companies for the third hypothesis $\left(\mathrm{H}_{3}\right)$ is mixed. That is profitability has a significant effect on total debt ratio, but profitability does not have a significant relationship with long-term debt ratio. Also, according to the estimated regression coefficient, the total debt ratio is negative, it shows that with the increase in the profitability of Australian companies, the ratio of total debt is reduced. This is consistent with Sakatan's (2010) research. Therefore, the results show that profitability in the developing country of Iran and the developed country of Australia do not equally affect the structure of capital. Considering regression coefficient total debt, by increasing the company's profitability, Iranian and Australian executives tend to use equity as the primary source of financing. Considering the estimated regression coefficient of leverage ratios (TD, LD), it can be argued that with increasing profitability, the desire of Iranian directors to use long-term and short-term debt simultaneously is reduced, but the percentage of long-term debt use is greater than short-term debt. On the other hand, for the developed country of Australia, changes in the long-term debt ratio are not affected by the profitability of companies.

Contrary to the fourth hypothesis $\left(\mathrm{H}_{4}\right)$, liquidity in both Iranian and Australian stock exchanges has no significant effect on total debt ratio (TD) and long-term debt ratio (LD) as capital structure indices. That is, variation in leverage ratios is not affected by liquidity this result shows that the effect of liquidity on company leverage does not vary by the degree of development of countries. This is consistent with Belkhir et al. (2015).

According to the fifth hypothesis $\left(\mathrm{H}_{5}\right)$, the ratio of asset utilization on both the ratio of total debt and long-term debt ratio as leverage indexes in the Iranian stock market has been affected and given the estimated regression coefficient for this effect, is positive. This means that by increasing the efficiency of Iranian companies in using assets to generate income, the ratio of total debt and long-term debt ratios will increase. This is consistent with Alipour et al. (2015). This relation stems from the facts that, according to the agency theory, by increasing asset utilization ratio, the cash flow of the company increases, which tempts the managers to imprecisely spend the cash flow for their interests, such as achieving maximum reward (Alipour et al., 2015). In other words, in public companies due to the separation of ownership and management, shareholders cannot follow the manager's actions on a daily basis to make sure that the manager's decisions are by the interests of the shareholders (Forouzande, 2013). Therefore, to comply with the goals of the manager and shareholders, appropriate control methods should be created in the company; one of the control methods is the financing of the company through debt. Using debt as a primary source of financing can reduce the agency cost for two reasons; first, with the increase in the amount of debt in the capital structure, the risk of bankruptcy increases. Hence, managers will have to bring the efficiency and effectiveness of the company to a level higher to minimize bankruptcy risk. Managers' motivation for better performance can be to maintain a job position, maintain professional reputation and reward (Heydari et al., 2015). Second, creditors expect their investments in the company to be guaranteed and the risk of bankruptcy minimized. Hence, creditors will have more 
incentive to supervise the activities of managers, including controlling cash, controlling the remuneration of directors (Heydari et al., 2015). Results for the Australian companies, according to the fifth hypothesis (H5), the ratio of asset utilization has significantly affected to total debt and long-run debt. Given the estimated regression coefficient for this effect, are positive and negative respectively. This is consistent with Feidakis and Rovolis (2007).Therefore, the results show that the Asset Utilization Ratio in the developing country of Iran and the developed country of Australia do not equally affect capital structure. Considering regression coefficient total debt, by increasing asset utilization ratio, Iranian and Australian executives tend to use debt as the primary source of financing.

The results for the Iranian companies for the sixth hypothesis $\left(\mathrm{H}_{6}\right)$ has been mixed. This means that business risk has a significant relationship with total debt ratio, but the effect of Iranian business risk on long-term debt ratio is not significant. Also, according to the estimated regression coefficient, this effect is negative for the total debt ratio which shows that with the increase in the business risk of Iranian companies, the total debt ratio is reduced. This result is in line with the researchers of Sakatan (2010), Rajagopal (2011), Alipour et al. (2015), Kopyakova (2017). The presence of a negative correlation support POT and TOT predictions. TOT states that with the company's increasing income fluctuations, the company's risk of bankruptcy will increase, and as a result, companies' tendency to use debt is reduced. In other words, by increasing the revenue fluctuation, the company has lower ability to repay their debt in an economic depression, which could lead to legal action against the company from creditors. POT also argues that increasing the revenue fluctuation increases the problem of adverse selection resulting from the asymmetry of information between the company and the creditor. Therefore, managers will have less willingness to use debt (Koksal and Orman, 2014).Contrary to the sixth hypothesis (H6), the business risk in the Australian stock exchange did not have a significant effect on the total debt ratio and long-term debt ratio as capital structure indices. This result is in line with Taleb (2015). Therefore, the results show that business risk in the developing country of Iran and the developed country of Australia do not equally affect the structure of capital. Considering total debt ratio, with increasing business risk, Iranian executives use equity as the main source of financing. However, for Australia's developed country the business risk does not affect capital structure decision.

\subsection{Robustness Test}

The results of regression analysis will have the necessary reliability if there is certainty about the confirmation of classical assumptions. In this section, these classical assumptions are considered for regression models of the Iranian and Australian companies.

\subsubsection{Non-Collinearity of Independent Variables}

Another classical assumption in the linear regression model is non-collinearity of the independent variables. To investigate the collinearity or non-collinearity of the independent variables, the Correlation coefficient is used (Gujarati and Porter, 2009).

Table 9. Correlation coefficients of independent variables (Firms listed on Iran Stock Exchange)

\begin{tabular}{|c|c|c|c|c|c|c|c|c|}
\hline Variable & $\begin{array}{c}\text { Total Debt } \\
\text { Ratio }\end{array}$ & $\begin{array}{l}\text { Long-term } \\
\text { Debt Ratio }\end{array}$ & $\begin{array}{c}\text { Tangib } \\
\text { ility }\end{array}$ & Size & $\begin{array}{c}\text { Profitabil } \\
\text { ity }\end{array}$ & Liquidity & $\begin{array}{c}\text { Asset } \\
\text { utilization ratio }\end{array}$ & Risk \\
\hline $\begin{array}{l}\text { Total Debt } \\
\text { Ratio (TD) }\end{array}$ & 1 & & & & & & & \\
\hline Long term & & & & & & & & \\
\hline $\begin{array}{l}\text { Debt Ratio } \\
\text { (LD) }\end{array}$ & $0.845^{*}$ & 1 & & & & & & \\
\hline $\begin{array}{l}\text { Tangibility } \\
\text { (FA) }\end{array}$ & $0.739^{*}$ & $0.829^{*}$ & 1 & & & & & \\
\hline Size (SIZE) & $-0.07 *$ & -0.048 & $-0.061 *$ & 1 & & & & \\
\hline $\begin{array}{l}\text { Profitability } \\
\text { (PROF) }\end{array}$ & $-0.205^{*}$ & $0.13^{*}$ & $0.306^{*}$ & 0.014 & 1 & & & \\
\hline $\begin{array}{l}\text { Liquidity } \\
\text { (LIQ) }\end{array}$ & -0.01 & -0.01 & -0.01 & $-0.069 *$ & -0.028 & 1 & & \\
\hline $\begin{array}{c}\text { Asset } \\
\text { utilization } \\
\text { ratio (AUR) }\end{array}$ & $0.679 *$ & $0.495^{*}$ & $0.445^{*}$ & $-0.174 *$ & $0.23^{*}$ & -0.016 & 1 & \\
\hline Risk (RISK) & $0.184 *$ & $0.181^{*}$ & $0.212 *$ & -0.032 & $0.122 *$ & -0.002 & $0.151^{*}$ & 1 \\
\hline
\end{tabular}

* Correlation is significant at the 0.05 level 
Table 10. Correlation coefficients of independent variables (Firms listed on Australian Stock Exchange)

\begin{tabular}{|c|c|c|c|c|c|c|c|c|}
\hline Variable & $\begin{array}{l}\text { Total } \\
\text { Debt } \\
\text { Ratio }\end{array}$ & $\begin{array}{c}\text { Long-ter } \\
\text { m Debt } \\
\text { Ratio }\end{array}$ & Tangibility & Size & $\begin{array}{c}\text { Profita } \\
\text { bility }\end{array}$ & $\begin{array}{l}\text { Liquidit } \\
\quad y\end{array}$ & $\begin{array}{c}\text { Asset } \\
\text { utilization } \\
\text { ratio }\end{array}$ & Risk \\
\hline $\begin{array}{l}\text { Total Debt } \\
\text { Ratio }\end{array}$ & 1 & & & & & & & \\
\hline $\begin{array}{l}\text { Long term } \\
\text { Debt Ratio }\end{array}$ & $0.102^{*}$ & 1 & & & & & & \\
\hline Tangibility & $-0.004 *$ & -0.032 & 1 & & & & & \\
\hline Size & $-0.138 *$ & $0.281 *$ & $-0.058^{*}$ & 1 & & & & \\
\hline Profitability & $-0.928 *$ & 0.028 & -0.001 & $0.12 *$ & 1 & & & \\
\hline $\begin{array}{l}\text { Liquidity } \\
\text { Asset }\end{array}$ & -0.009 & $-0.054^{*}$ & $0.537^{*}$ & $-0.126^{*}$ & -0.008 & 1 & & \\
\hline $\begin{array}{l}\text { utilization } \\
\text { ratio }\end{array}$ & $0.146^{*}$ & 0.004 & -0.003 & $-0.125^{*}$ & $-0.056^{*}$ & -0.031 & 1 & \\
\hline Risk & $0.062 *$ & 0.011 & -0.003 & $-0.223^{*}$ & -0.057 & -0.004 & 0.009 & 1 \\
\hline
\end{tabular}

* Correlation is significant at the 0.05 level

The results of these tables show that the values of the correlation coefficient of the independent variables for both groups of Iranian and Australian companies are in a range close to zero, suggesting that there is a weak relationship between the independent variables.

\subsubsection{Homoscedasticity Residual Terms}

Another assumption of the linear regression model is that error variance should be constant. In this research, the White test is used to test homoscedasticity in panel data (Gujarati and Porter, 2009). Table 11 shows the results of the White test for each model, dependent variable, and country.

Table 11. White test results

\begin{tabular}{lcccc}
\hline Stock Exchange & Dependent Variable & Statistic & Value & Significance Level \\
\hline \multirow{4}{*}{ Iran } & \multirow{2}{*}{ TD } & F-statistic & 182.67 & 0.000 \\
& \multirow{3}{*}{ LD } & Obs*R-squared & 820.31 & 0.000 \\
& \multirow{2}{*}{ TD } & F-statistic & 92.49 & 0.000 \\
& \multirow{2}{*}{ Australia } & Obs*R-squared & 669.03 & 0.000 \\
& LD & F-statistic & 4.09 & 0.000 \\
& & Obs*R-squared & 81.40 & 0.000 \\
& & F-statistic & 0.45 & 0.983 \\
& & Obs*R-squared & 9.65 & 0.983
\end{tabular}

In the White test, the null hypothesis implies Homoscedasticity and the alternative hypothesis implies variance heterogeneity of residual terms. Regarding the values reported in table 11, among the models, the problem of variance heterogeneity exists exist in the first, second, and third models. To eliminate an homoscedasticity, different methods such as Generalized Least Square (GLS) have been proposed by economic experts (Gujarati and Porter, 2009). In this research, given the problem of variance heterogeneity, Generalized Least Square (GLS) method has been used in the estimation of the first and third models to determine the factors affecting capital structure of the companies.

\subsubsection{Non-Autocorrelation of Residual Terms}

Finally, the last classical assumption is related to non-autocorrelation of residual terms in linear regression models. In other words, residual terms should not be related to each other at different time periods, and the violation of this 
assumption creates a problem called autocorrelation.

For autocorrelation, Durbin-Watson statistic is used (Gujarati and Porter, 2009). Durbin-Watson values of each model are presented in Table 12.

Table 12. Durbin-Watson statistic values

\begin{tabular}{ccc}
\hline Stock Exchange & Dependent Variable & Durbin-Watson \\
\hline \multirow{2}{*}{ Iran } & Total Debt Ratio & 1.49 \\
& Long-term Debt Ratio & 1.59 \\
\multirow{2}{*}{ Australia } & Total Debt Ratio & 1.56 \\
& Long-term Debt Ratio & 1.65 \\
\hline
\end{tabular}

Scholars have suggested that in the range (1 to 3), it can be assured to a remarkable degree that the problem of autocorrelation does not impinge the accuracy of regression results (Gujarati and Porter, 2009)

\subsection{Adjustment Speed}

At the last part of data analysis, adjustment speed of capital structure in the Iranian and Australian companies will be analyzed to calculate the adjustment speed in each country.

The factors affecting the capital structure in previous sections have been used To calculate adjustment speed, in which the dependent variable (i.e., capital structure indices such as total debt ratio and long-term debt ratio), with the time lag of $\mathrm{t}-1$, appear at the right side of the regression model as an independent variable alongside with other factors affecting the capital structure. Finally, by estimating the regression model, we can determine the regression coefficient of the lagged dependent variable and, by reducing this coefficient from the number one, the obtained value is considered as the adjustment speed of capital structure.

In table 13, according to the results of the Hausman test, panel fixed effects are used to estimate adjustment speed in the Iranian companies. In addition to panel fixed effects, in order to ensure the robustness of the findings, GMM method is used to determine adjustment speed of the Iranian companies and compare the two methods (Oino and Ukaegbu, 2015).

Table 13. Adjustment speed of capital structure of the companies in Iran stock exchange

\begin{tabular}{|c|c|c|c|c|c|c|c|c|}
\hline \multirow{4}{*}{$\begin{array}{c}\text { Model } \\
\text { Dependent } \\
\text { variable } \\
\text { Estimating } \\
\text { method } \\
\text { Independe } \\
\text { nt Variable }\end{array}$} & \multirow{2}{*}{\multicolumn{4}{|c|}{$\begin{array}{c}\text { First } \\
\text { Total Debt Ratio }\end{array}$}} & \multirow{2}{*}{\multicolumn{4}{|c|}{$\begin{array}{c}\text { Second } \\
\text { Long term Debt Ratio }\end{array}$}} \\
\hline & & & & & & & & \\
\hline & \multicolumn{2}{|c|}{ Panel Fixed Effects } & \multicolumn{2}{|c|}{ GMM } & \multicolumn{2}{|c|}{ Panel Fixed Effects } & \multicolumn{2}{|c|}{ GMM } \\
\hline & $\begin{array}{c}\text { Coefficie } \\
\text { nt }\end{array}$ & $\begin{array}{l}\text { t-statistic } \\
\text { Prob } \\
\text { (t-statistic) }\end{array}$ & $\begin{array}{c}\text { Coeffici } \\
\text { ent }\end{array}$ & $\begin{array}{l}\text { t-statistic } \\
\text { Prob } \\
\text { (t-statistic) }\end{array}$ & $\begin{array}{c}\text { Coeffici } \\
\text { ent }\end{array}$ & $\begin{array}{l}\text { t-statistic } \\
\text { Prob } \\
\text { (t-statistic) }\end{array}$ & $\begin{array}{c}\text { Coeffici } \\
\text { ent }\end{array}$ & $\begin{array}{l}\text { t-statistic } \\
\text { Prob } \\
\text { (t-statistic) }\end{array}$ \\
\hline $\mathrm{TD}(-1)$ & 0.081 & $\begin{array}{c}7.332 \\
(0.000)\end{array}$ & 0.002 & $\begin{array}{c}2.728 \\
(0.006)\end{array}$ & & & & \\
\hline $\mathrm{LD}(-1)$ & & & & & 0.056 & $\begin{array}{c}4.486 \\
(0.000)\end{array}$ & 0.006 & $\begin{array}{c}2.151 \\
(0.031)\end{array}$ \\
\hline $\begin{array}{l}\text { Tangibility } \\
\text { (FA) }\end{array}$ & 0.547 & $\begin{array}{l}34.712 \\
(0.000)\end{array}$ & -0.099 & $\begin{array}{l}-0.336 \\
(0.736)\end{array}$ & 0.206 & $\begin{array}{l}45.966 \\
(0.000)\end{array}$ & -0.730 & $\begin{array}{l}-2.912 \\
(0.003)\end{array}$ \\
\hline Size (SIZE) & -0.117 & $\begin{array}{l}-1.982 \\
(0.047)\end{array}$ & 0.066 & $\begin{array}{c}0.584 \\
(0.559)\end{array}$ & -0.029 & $\begin{array}{l}-1.746 \\
(0.081)\end{array}$ & -0.096 & $\begin{array}{l}-0.778 \\
(0.436)\end{array}$ \\
\hline $\begin{array}{c}\text { Profitability } \\
\text { (PROF) }\end{array}$ & -1.389 & $\begin{array}{r}-11.002 \\
(0.000)\end{array}$ & -0.237 & $\begin{array}{l}-0.921 \\
(0.035)\end{array}$ & -0.262 & $\begin{array}{l}-7.256 \\
(0.000)\end{array}$ & -0.175 & $\begin{array}{l}-0.650 \\
(0.515)\end{array}$ \\
\hline $\begin{array}{l}\text { Liquidity } \\
\text { (LIQ) }\end{array}$ & 0.000 & $\begin{array}{c}0.476 \\
(0.633)\end{array}$ & 0.000 & $\begin{array}{l}-0.384 \\
(0.70)\end{array}$ & 0.000 & $\begin{array}{c}0.553 \\
(0.579)\end{array}$ & 0.000 & $\begin{array}{c}0.880 \\
(0.379)\end{array}$ \\
\hline $\begin{array}{c}\text { Asset } \\
\text { utilization }\end{array}$ & 1.014 & $\begin{array}{l}33.070 \\
(0.000)\end{array}$ & -0.018 & $\begin{array}{l}-0.155 \\
(0.876)\end{array}$ & 0.120 & $\begin{array}{r}-13.804 \\
(0.000)\end{array}$ & 0.058 & $\begin{array}{c}0.719 \\
(0.471)\end{array}$ \\
\hline
\end{tabular}




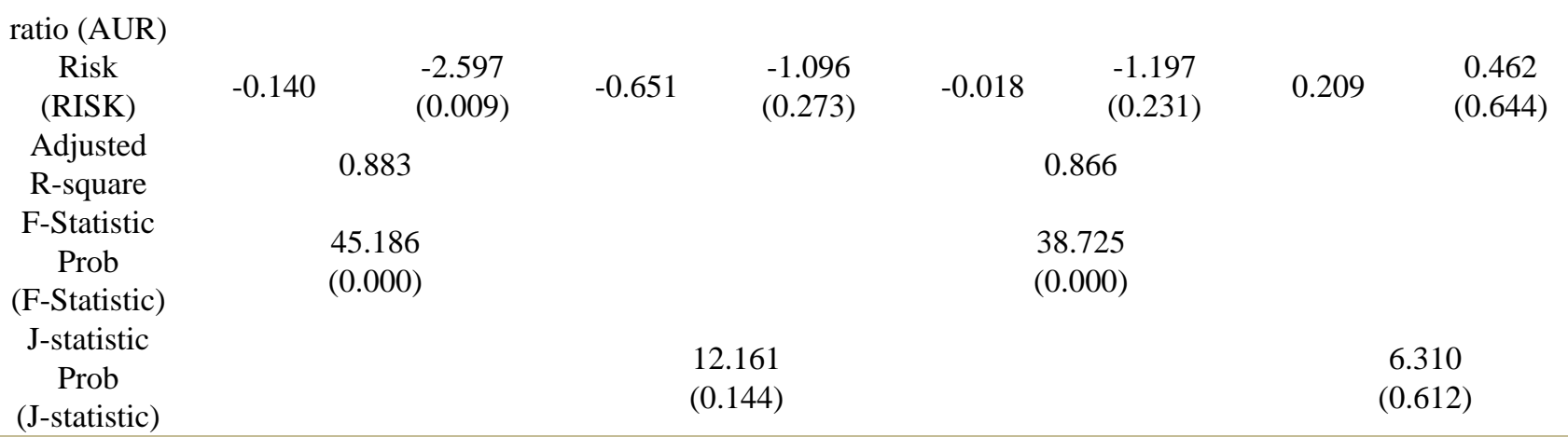

Table 13 offers the results of the estimation of the adjustment speed for the two regression models. In the first model, the lagged total debt ratio TD (-1) and in the second model, the lagged long-term debt ratio LD (-1), have been used at the right side of the regression model to calculate adjustment speed of the Iranian companies as the independent variable.

The results of the first and the second model will be discussed in continue. In the first model, t-statistic and significance of TD (-1) are 7.332 and 0.000 respectively, suggesting that regression coefficient of this variable is significant. About the regression estimation of 0.081 , it can be said that adjustment speed of the Iranian companies is $91 \%(1-0.081=0.919)$. Therefore, Iranian companies are getting closer to the target leverage by $91 \%$ each year; in other words, Iranian companies reach the target leverage in less than two years $(100 \div 91=1.09)$. Based on the GMM method in the first model, t-statistic and significant level of TD (-1) are 2.728 and 0.006 respectively, indicating that regression coefficient of this variable is significant. Regarding the regression coefficient of 0.002 , it can be said that adjustment speed of Iranian companies is $99 \%(1-0.002=0.998)$. The Sargan test is also used to assess the significance and overall fitness of the model. According to the results of table 13, in the first model, J-statistic and significance level are 12.161 and 0.144 respectively. Thus, the null hypothesis is confirmed, stating that instrumental variables used in the model estimation have the required validity (Gujarati and Porter, 2009). Therefore, the results in both methods are close to each other for the first model. High adjustment speed in the GMM method is consistent with the results of Flannery and Rangan (2006), stating that OLS estimates show a minor adjustment speed.

In the second model of table 13, t-statistic and significance level of LD (-1) are 4.486 and 0.000 respectively, indicating that the regression coefficient of this variable is significant. About the regression coefficient of 0.056 , it can be said that adjustment speed for the Iranian companies is $94 \%(1-0.056=0.944)$. Thus, Iranian companies are getting closer to the target leverage by $94 \%$ each year; in other words, Iranian companies reach the target leverage in less than two years $(100-0.94=1.06)$. Based on the GMM method in the second model, t-statistic and significance level of LD (-1) are 2.151 and 0.031 respectively, suggesting that the regression coefficient of this variable is significant. About the regression coefficient of 0.006, it can be argued that adjustment speed of the Iranian companies be $99 \%(1-0.006=0.994)$. The Sargan test is also used to assess the significance and overall fit of the model. Based on the results of table 13, in the second model, the value of J-statistic and significance level are 6.310 and 0.612 respectively; hence, the null hypothesis is confirmed, stating that instrumental variables used in the model estimation have the required validity (Gujarati and Porter, 2009).

Table 14 provides an analysis for determining adjustment speed of the Australian companies. According to the results of the Hausman test for, random panel effect has been used to estimate the adjustment speed for the Australian companies. In addition to the random panel effect, in order to ensure the robustness of the findings, GMM method is used to determine adjustment speed of the Australian companies and compare the two methods (Oino and Ukaegbu, 2015). 
Table 14. Adjustment speed of capital structure of the companies in Australian Stock Exchange

\begin{tabular}{|c|c|c|c|c|c|c|c|c|}
\hline \multirow{4}{*}{$\begin{array}{c}\text { Model } \\
\text { Dependent } \\
\text { variable } \\
\text { Estimation } \\
\text { method } \\
\text { Independent } \\
\text { Variables }\end{array}$} & \multirow{2}{*}{\multicolumn{4}{|c|}{$\begin{array}{c}\text { Third } \\
\text { Total Debt Ratio }\end{array}$}} & \multirow{2}{*}{\multicolumn{4}{|c|}{$\begin{array}{c}\text { Fourth } \\
\text { Long term Debt Ratio }\end{array}$}} \\
\hline & & & & & & & & \\
\hline & \multicolumn{2}{|c|}{ Panel Random Effect } & \multicolumn{2}{|c|}{ GMM } & \multicolumn{2}{|c|}{ Panel Random Effect } & \multicolumn{2}{|c|}{ GMM } \\
\hline & Coefficient & $\begin{array}{l}\text { t-statistic } \\
\text { Prob } \\
\text { (t-statistic) }\end{array}$ & Coefficient & $\begin{array}{l}\text { t-statistic } \\
\text { Prob } \\
\text { (t-statistic) }\end{array}$ & Coefficient & $\begin{array}{l}\text { t-statistic } \\
\text { Prob } \\
\text { (t-statistic) }\end{array}$ & Coefficient & $\begin{array}{l}\text { t-statistic } \\
\text { Prob } \\
\text { (t-statistic) }\end{array}$ \\
\hline $\mathrm{TD}(-1)$ & 0.080 & $\begin{array}{l}11.790 \\
(0.000)\end{array}$ & 0.015 & $\begin{array}{c}3.449 \\
(0.000)\end{array}$ & & & & \\
\hline $\mathrm{LD}(-1)$ & & & & & 0.384 & $\begin{array}{l}16.983 \\
(0.000)\end{array}$ & 0.083 & $\begin{array}{c}2.787 \\
(0.022)\end{array}$ \\
\hline $\begin{array}{l}\text { Tangibility } \\
\text { (FA) }\end{array}$ & 0.000 & $\begin{array}{c}0.667 \\
(0.504)\end{array}$ & 0.000 & $\begin{array}{l}-0.056 \\
(0.954)\end{array}$ & 0.000 & $\begin{array}{l}-0.201 \\
(0.840)\end{array}$ & 0.000 & $\begin{array}{l}-0.789 \\
(0.430)\end{array}$ \\
\hline Size (SIZE) & -0.016 & $\begin{array}{l}-1.511 \\
(0.131)\end{array}$ & -0.195 & $\begin{array}{l}-0.643 \\
(0.519)\end{array}$ & 0.030 & $\begin{array}{c}6.452 \\
(0.000)\end{array}$ & 0.134 & $\begin{array}{c}0.877 \\
(0.380)\end{array}$ \\
\hline $\begin{array}{l}\text { Profitability } \\
\text { (PROF) }\end{array}$ & -0.172 & $\begin{array}{c}-136.588 \\
(0.000)\end{array}$ & -0.110 & $\begin{array}{l}-1.559 \\
(0.119)\end{array}$ & 0.000 & $\begin{array}{l}-0.440 \\
(0.659)\end{array}$ & 0.003 & $\begin{array}{c}0.375 \\
(0.707)\end{array}$ \\
\hline $\begin{array}{l}\text { Liquidity } \\
\text { (LIQ) }\end{array}$ & 0.000 & $\begin{array}{l}-2.338 \\
(0.019)\end{array}$ & 0.000 & $\begin{array}{l}-0.419 \\
(0.674)\end{array}$ & 0.000 & $\begin{array}{c}0.515 \\
(0.606)\end{array}$ & 0.000 & $\begin{array}{c}0.765 \\
(0.444)\end{array}$ \\
\hline $\begin{array}{c}\text { Asset } \\
\text { utilization } \\
\text { ratio (AUR) }\end{array}$ & 0.132 & $\begin{array}{c}7.913 \\
(0.000)\end{array}$ & -0.139 & $\begin{array}{l}-0.975 \\
(0.329)\end{array}$ & -0.025 & $\begin{array}{l}-3.639 \\
(0.000)\end{array}$ & 0.016 & $\begin{array}{c}0.223 \\
(0.823)\end{array}$ \\
\hline Risk (RISK) & 0.000 & $\begin{array}{c}0.735 \\
(0.462)\end{array}$ & -0.006 & $\begin{array}{l}-0.767 \\
(0.443)\end{array}$ & 0.000 & $\begin{array}{c}1.338 \\
(0.181)\end{array}$ & -0.004 & $\begin{array}{l}-1.094 \\
(0.274)\end{array}$ \\
\hline $\begin{array}{l}\text { adjusted } \\
\text { R-Square }\end{array}$ & \multicolumn{2}{|c|}{0.886} & \multicolumn{6}{|c|}{0.253} \\
\hline $\begin{array}{l}\text { F-Statistic } \\
\text { Prob } \\
\text { (F-Statistic) }\end{array}$ & \multicolumn{2}{|c|}{$\begin{array}{c}1246.691 \\
(0.000)\end{array}$} & \multicolumn{6}{|c|}{$\begin{array}{l}55.478 \\
(0.000)\end{array}$} \\
\hline $\begin{array}{l}\text { J-statistic } \\
\text { Prob } \\
\text { (J-statistic) }\end{array}$ & \multicolumn{4}{|c|}{$\begin{array}{c}4.885 \\
(0.769)\end{array}$} & & & \multicolumn{2}{|c|}{$\begin{array}{c}6.599 \\
(0.580)\end{array}$} \\
\hline
\end{tabular}

In the third model, t-statistic and significance level of TD (-1) are 11.790 and 0.000 respectively, indicating that the regression coefficient of this variable is significant. About the regression of 0.080 , it can be said that adjustment speed of the Australian companies is $92 \%(1-0.080=0.92)$. Therefore, Australian companies are getting closer to the target leverage by $92 \%$ each year; in other words, Australian companies reach the target leverage in less than two years $(100 \div 92=1.08)$. Based on the GMM method in the third model, t-statistic and significance level of TD $(-1)$ are 3.449 and 0.000 respectively, indicating that the regression coefficient of this variable is significant. About the regression coefficient of 0.015, it can be argued that adjustment speed for the Australian companies be 98\% (1-0.015 $=0.985)$. The Sargan test is also used to assess the significance and overall fitness of the model. Based on the results of table 14, in the third model, J-statistic and significance level are 4.885 and 0.769 respectively. Thus, the null hypothesis is confirmed, stating that the instrumental variables used in the model estimation are valid (Gujarati and Porter, 2009).

In the fourth model of table 14, t-statistic and significance level of LD (-1) are 16.983 and 0.000 respectively, showing that the regression coefficient of this variable is significant. About the regression coefficient of 0.384 , it can be said that adjustment speed of the Australian companies is $61 \%(1-0.384=0.616)$. Thus, Australian companies are approaching target leverage by $61 \%$ each year, meaning that Australian companies reach the target leverage in less than two years $(100 \div 61=1.63)$. Based on the GMM method in the fourth model, t-statistic and significance level of $\mathrm{LD}(-1)$ are 2.787 and 0.022 respectively, showing that the regression coefficient is significant. About the regression coefficient of 0.083 , it can be argued that adjustment speed for the Australian companies be $91 \%(1-0.083=0.917)$. 
The Sargan test is also used to assess the significance and overall fitness of the model. Based on the results of table 14, in the fourth model, J-statistic and significance level are 6.599 and 0.580 respectively. Thus, the null hypothesis is confirmed, stating that the instrumental variables used in the model estimation are valid (Gujarati and Porter, 2009).

\section{Discussion and Investigation}

\subsection{Which Theory (Trade off or Pecking Order) Reflects the Capital Structure Choice More Accurately?}

The results of this study show that, in general, the dynamic trade-off theory describes the capital structure of Iranian and Australian companies better than pecking order theory. In table 15, prediction of pecking order theory and trade-off theory along with the empirical findings of this research have been shown.

Table 15. Comparison of theoretical predictions with data facts

\begin{tabular}{|c|c|c|c|c|c|c|c|}
\hline \multirow{3}{*}{$\begin{array}{c}\text { Determinan } \\
\text { ts }\end{array}$} & \multirow{3}{*}{$\begin{array}{l}\text { Pecking } \\
\text { order } \\
\text { Theory } \\
\text { (POT) }\end{array}$} & \multicolumn{2}{|c|}{ Trade-off Theory (TOT) } & \multicolumn{4}{|c|}{ Results } \\
\hline & & \multirow{2}{*}{$\begin{array}{c}\text { Static } \\
\text { Tradeoff } \\
\text { Theory }\end{array}$} & \multirow{2}{*}{$\begin{array}{c}\text { Dynamic } \\
\text { Tradeoff } \\
\text { Theory }\end{array}$} & \multicolumn{2}{|c|}{ Iran } & \multicolumn{2}{|c|}{ Australia } \\
\hline & & & & TD & LD & TD & LD \\
\hline $\begin{array}{l}\text { Tangibility } \\
\text { (FA) }\end{array}$ & - & + & + & + & + & No effect & $\begin{array}{l}\text { No } \\
\text { effect }\end{array}$ \\
\hline $\begin{array}{l}\text { Firm Size } \\
\text { (SIZE) }\end{array}$ & - & + & + & - & $\begin{array}{l}\text { No } \\
\text { effect }\end{array}$ & - & + \\
\hline $\begin{array}{l}\text { Profitability } \\
\text { (PROF) }\end{array}$ & - & + & - & - & - & - & $\begin{array}{l}\text { No } \\
\text { effect }\end{array}$ \\
\hline $\begin{array}{c}\text { Business } \\
\text { Risk } \\
\text { (RISK) }\end{array}$ & - & - & - & - & $\begin{array}{l}\text { No } \\
\text { effect }\end{array}$ & No effect & $\begin{array}{l}\text { No } \\
\text { effect }\end{array}$ \\
\hline
\end{tabular}

As shown in the table, the positive relationship of tangibility with the leverage ratio (TD, LD) is positive for the Iranian companies, which is consistent with the prediction of the TOT. However, this relationship has not been significant for Australian companies. Results for firm size have been mixed. While the positive firm size relationship with the leverage ratio (LD) for Australian companies is consistent with the TOT, there is a negative correlation between the size of the company and the leverage ratio (TD) for the Iranian and Australian companies, which is consistent with the POT forecast. Also, the negative relationship between profitability and leverage ratio (TD, LD) for Iranian companies is in line with the dynamic trade-off theory and pecking order theory. According to POT, companies do not have a target leverage, and corporate financing is based on a specific hierarchy. However, as a result of this study, it has been shown that Iranian and Australian companies are moving at high speed to the optimal capital structure, which is in line with the dynamic trade-off theory. Finally, the negative business risk relationship with the leverage ratio (TD) for Iranian companies is consistent with POT and TOT, while for Australian firms, the relationship between business risk and leverage ratio (TD, LD) has not been significant.

According to the explanation, although none of the theories (TOT, POT), fully capture the capital structure of Iranian and Australian companies, however, it can be argued that dynamic trade-off theory has a better prediction of the financial behavior of Iranian and Australian companies. This is the result in line with Oino and Ukaegbu (2015).

7.2 Does Firm Leverage Adjustment Speed in the Developing Country of Iran and the Developed Country of Australia Affect Capital Structure Equally?

The results of this study confirm the existence of speed of adjustment that supports dynamic trade-off theory (Oino and Ukaegbu, 2015). According to this theory, companies modify the structure of capital gradually and only in periods where their leverage has a significant deviation from the target leverage ratio. It also suggests that companies, instead of having a precise target leverage, allow the leverage ratio to change in a domain (Dang, 2013). The speed of adjustment has important implications for the company for two reasons; First, since companies are active in the imperfect capital market and face with the problem of information asymmetry (Myers and Majluf, 1984) and the shock of a market such as credit limited (Baker and Wurgler, 2002) temporarily diverge from target leverage. Second, due to the cost of adjustments (such as transaction costs, legal and bank fees), companies cannot quickly offset the divergence from the target leverage (Supra et al., 2016). Therefore, Firms whose leverage ratio do not coincide with 
their target leverage will only adjust capital structure when the benefit of adjusting to being higher than cost (Dudley, 2007). In other words, whenever the adjustment cost is greater than the adjustment benefit, the company has a lower speed of adjustment rate to the target leverage ratio, and whenever the benefits of restructuring the capital structure are higher than the cost, the company has a higher speed of adjustment rate to target leverage ratio. (Mahakud and Mukherjee, 2011) Therefore, managers need to adjust the company's financial policies based on the speed of adjustment of capital structure, to reduce adjustment costs by identifying the new financial resources if the adjustment speed is low. Investors can also reduce the risk of investing by knowing the speed of moderation by choosing firms with higher adjustment speeds.

\section{References}

Abdeljawad, I., \& Mat Nor, F. (2017). The Capital Structure Dynamics of Malaysian Firms: Timing Behavior vs. Adjustment Towards the Target. International Journal of Managerial Finance, 13(3), 226-245. https://doi.org/10.1108/IJMF-09-2015-0170

Abdul Hadi, A.R., \& Suryanto, T. (2016). Capital Structure Determinants: Evidence from Palestine and Egypt Stock Exchange. Journal of Islam Economics and Business, 1(2), 118-130. https://doi.org/10.24042/febi.v1i2.147

Adrian, T., Boyarchenko, N., \& Song Shin, H. (2016). On the Scale of Financial Intermediaries, Federal Reserve Bank of New York Staff Reports, 743, 1-37. Retrieved October 2017, from https://econpapers.repec.org/scripts/redir.pf?u=https $\% 3 \mathrm{~A} \% 2 \mathrm{~F} \% 2 \mathrm{Fwww}$.newyorkfed.org $\% 2$ Fmedialibrary $\% 2 \mathrm{Fm}$ edia\%2Fresearch\%2Fstaff_reports\%2Fsr743.pdf;h=repec:fip:fednsr:743

Afshari Manesh, F. (2015). Investigating the Effect of the Industrial Type on the Capital Structure of Petrochemical Industry. Khatam Institute of Higher Education Master's degree dissertation. [Persian]

Ahmad, R., \& Etudaiye-Muhtar, O.F. (2017). Dynamic Model of Optimal Capital Structure: Evidence from Nigerian Listed Firms. Global Business Review, 18(3), 590-604. https://doi.org/10.1177/0972150917692068

Alipour, M., Seddigh Mohammadi, M.F., \& Derakhshan, H. (2015). Determinants of Capital Structure: an Empirical Study of Firms in Iran. International Journal of Law and Management, 57(1), 53-83. https://doi.org/10.1108/IJLMA-01-2013-0004

Babu, N.S., \& Chalam, G.V. (2016). Capital Structure and Its Determinants of the Automobile Companies in India: An Empirical Analysis. EPRA International Journal of Economic and Business Review, 4(7), 161-170. Retrieved from October 2016, from http://eprawisdom.com/hits?id=1035

Baker, H.K., \& Martin, G.S. (2011). Trade off, Pecking Order, Signaling and Market Timing Models. Capital Structure and Corporate Financing Decisions: Theory, Evidence and Practice. John Wily and Sons. https://doi.org/10.1002/9781118266250

Baker, M., \& Wurgler, J. (2002). Market Timing and Capital Structure. The Journal of Finance, 57(1), 1-32. https://doi.org/10.1111/1540-6261.00414

Balios, D., Daskalakis, N., Eriotis, N., Vasiliou, D., \& McMillan, D. (2016). SMEs Capital Structure Determinants During Severe Economic Crisis: The Case of Greece. Cogent Financial Economics, 4(1), 1-11. https://doi.org/10.1080/23322039.2016.1145535

Belkhir, M., Mayer h, A., \& Awartani, B. (2016). Institutions and Corporate Capital Structure in MENA Region. Emerging Markets Review, 26, 99-129. https://doi.org/10.1016/j.ememar.2016.01.001

Booth, L., Aivazian, V., Demirguc-Kunt, A., \& Maksimovic, V. (2001). Capital Structure in Developing Countries. The Journal of Finance. https://doi.org/10.1111/0022-1082.00320

Brealey, R.A., Meyers, S.C., \& Allen, A. (2010). Principle of Corporate Finance, Concise (2nd ed.). France: McGraw-Hill Education

Caprio, G., \& Demirguc-Kunt, A. (1997). The Role of Long-Term Finance: Theory and Evidence. The World Bank, Policy Research Working Paper.

Chen, J.J. (2004). Determinants of Capital Structure of Chinese-Listed' Companies. Journal of Business Research, 57(12), 1341-1351. https://doi.org/10.1016/S0148-2963(03)00070-5

Dang, V.A. (2013). Testing Capital Structure Theories Using Error Correction Models: Evidence from the UK, France, Germany. Applied Economics, 45(2), 171-190. http://dx.doi.org/10.1080/00036846.2011.597724

Daskalakis, N., \& Psillaki, M. (2008). Do Country or Firm Factors Explain Capital Structure? Evidence from SMEs in France and Greece. Applied Financial Economics, 18(2), 87-97. Retrieved October 2017, from https://ssrn.com/abstract=1341883 
Demirguc-Kunt, A., \& Maksimovic, V. (1996). Stock Market Development and Financing Choices of Firms. The World Bank Economic Review, 10(2), 341-369. Retrieved October 2017, from http://www.jstor.org/stable/3990066

Demirguc-Kunt, A., Martinez-Peria, M.S., \& Tressel, T. (2015). The impact of the global financial crisis on firms' capital structure (Working Paper), World Bank Group. Retrieved October 2017, from http://documents.worldbank.org/curated/en/965511468000625382/The-impact-of-the-global-financial-crisis-onfirms-capital-structure

Deposits. (2017). World Deposit Rates. Retrieved October 2017, from https://www.deposits.org/world-deposit-rates.html

Dudley, E. (2007). Testing Models of Dynamic Trade Off Theory. https://dx.doi.org/10.2139/ssrn.1030119

Ehrhardt, M.C., \& Brigham, E.F. (2017). Corporate Finance: A Focus Approach (6th ed.). South Western: College Publication.

Equitise. (2015). Alternative Finance in Australia. Retrieved October 2017, from https://www2.deloitte.com/au/en/pages/deloitte-private/articles/alternative-finance-in-australia.html

Fakhrhosseini, S.F., \& Sangdovini, M. (2016). Effect of Profitability on Capital Structure and Speed Adjustment: Empirical Examination in Listed Firms in the Tehran Stock Exchange. 2d International Conference on Accounting, Economics and Financial Management, Shahrekord, Payam Noor University of Shahrekord, Civilica. Retrieved October 2017, from https://www.civilica.com/Paper-AEFMC02-AEFMC02_185.html [Persian]

Fama, E.F., \& Frank. K.R. (2002). Testing Trade-Off and Pecking Order Predictions about Dividends and Debt. The Review of Financial Studies, 15(1), 1-33. Retrieved October 2017, from http://www.jstor.org/stable/2696797

Feidakis, A., \& Rovolis, A. (2007). Capital Structure Choice in European Union: Evidence from the Construction Industry. Applied Financial Economics, 17(12), 989-1002. https://doi.org/10.1080/09603100600749311

Filbeck, G., \& Gorman, R.F. (2000). Capital Structure and Asset Utilization: The Case of Resource Intensive Industries. Resources Policy, 26(4), 211-218. https://doi.org/10.1016/S0301-4207(00)00039-8

Fischer, E.O., Heinkel, R., \& Zechner, J. (1989). Dynamic Capital Structure Choice: Theory and Tests. The Journal of Finance, 44(1), 19-40. Retrieved October 2017, from http://www.jstor.org/stable/2328273

Flannery, M.J., \& Rangan, K.P. (2006). Partial Adjustment Toward Target Capital Structures. Journal of Financial Economics, 79, 469-506. https://dx.doi.org/10.2139/ssrn.467941

Forouzande, J. (2013). Agency Cost Theory. The Conference on Modern Management Sciences, Iran, Golestan. Civilica. Retrieved October 2017, from https://www.civilica.com/Paper-CMMS02-CMMS02_024.html [Persian]

Fosberg, R.H. (2013). Capital Structure and the Financial Crisis. Journal of Finance and Accountancy. Retrieved October 2017, from www.aabri.com/manuscripts/121213.pdf

Frank, M.Z., \& Goyal, V.Z. (2008b) 'Profits and Capital Structure', AFA 2009, San Francisco Meeting Paper. https://dx.doi.org/10.2139/ssrn.1104886

Frank, M.Z., \& Goyal, V.Z. (2009c). Capital Structure Decisions: Which Factors are Reliably Important?. Financial Management, 38(1), 1-37. https://doi.org/10.1111/j.1755-053X.2009.01026.x

Getzmann, A., Lang, S., \& Spremann, K. (2010). Determinants of Target Capital Structure and Adjustment Speed Evidence from Asian, European and US Capital Market. European Financial Management, 1-41. Retrieved October 2017, from https://www.alexandria.unisg.ch/publications/59839

Getzmann, A., Lang, S., \& Spremann, K. (2014). Target Capital Structure and Adjustment Speed in Asia', Asia-Pacific Journal of Financial Studied, 43(1), 1-30. https://doi.org/10.1111/ajfs.12038

Ghose, B. (2017). Impact of Business Group Affiliation on Capital Structure Adjustment Speed: Evidence from Indian Manufacturing Sector', Emerging Economy Studied, 3(1), 54-67. https://doi.org/10.1177/2394901517696605

Gorji, A., \& Ra'ee, R. (2015). Determining Capital Structure Adjustment Speed Using a Better Dynamic Model of Capital Structure with Emphasis on the Product Market Competition Factor. Financial Knowledge of Securities Analysis, 8(25), 43-67. Retrieved October 2017, from http://jfksa.srbiau.ac.ir/article_6495_en.html [Persian]

Graham, J.R., \& Leary, M.T. (2011). A Review of Empirical Capital Structure Research and Directions for the Future. Annual Review of Financial Economics, 3, 309-345. https://dx.doi.org/10.2139/ssrn.1729388 
Graham, J.R., \& Harvey, C.R. (2001). The Theory and Practice of Corporate Finance: Evidence from the Field. Journal of Financial Economics, 60(2-3), 187-243. https://doi.org/10.1016/S0304-405X(01)00044-7

Gujarati, D., \& Porter, D.C. (2009). Basic Econometrics (5th ed). Irwin: McGraw-Hill.

Haas, R., \& Peeters, M. (2006). The Dynamic Adjustment Towards Target Capital Structures of Firms in Transition Economies. Economics of Transition, 14(1), 133-169. Retrieved October 2017, from www.ebrd.com/downloads/research/economics/publications/EoT_by_RDH.pdf

Habibi, S., Abzari, M., \& Fathi, S. (2014). Determinants of Capital Structure: Meta-analysis. Asset Management and Financing, 2(1), 55-74. Retrieved October 2017, from http://amf.ui.ac.ir/article_19875_0.html [Persian]

Harris, M., \& Raviv, A. (1991). The Theory of Capital Structure. The Journal of Finance, 46(1), 297-355. Retrieved October 2017, from http://www.jstor.org/stable/2328697

Heydari, M., Didar, H., \& Ghaderi, B. (2015). Invasting the Effect of Agency Cost on Performance: The Structural Equation Modelling Approach. Quarterly Financial Accounting, 7(27), 77-101. Retrieved October 2017, from qfaj.ir/article-1-435-fa.pdf

Hitchner, J.R. (2017). Financial Valuation: Applications and Models+Website (4th ed.). Wiley Finance. https://doi.org/10.1002/9781119362814

Hovakimian, A., Hovakimian, G., \& Tehranian, H. (2004). Determinants of Target Capital Structure: The Case of Dual Debt and Equity Issues. Journal of Financial Economics, 71(3), 517-540. https://doi.org/10.1016/S0304-405X(03)00181-8

Huang, G., \& Song, F.M. (2006). The Determinants of Capital Structure: Evidence from China. China Economic Review, 17(1), 14-36. https://doi.org/10.1016/j.chieco.2005.02.007

Huang, R., \& Ritter, J.R. (2009). Testing Theories of Capital Structure and Estimating the Speed of Adjustment. The Journal of Financial and Quantitative Analysis, 44(2), 237-271. Retrieved October 2017, from http://www.jstor.org/stable/40505924

Imtiaz, M.F., Mahmud, K.H., \& Mallik, A. (2016). Determinants of Capital Structure and Testing of Applicable Theories: Evidence from Pharmaceutical Firms of Bangladesh. International Journal of Economics and Finance, 8(3), 23-32. http://dx.doi.org/10.5539/ijef.v8n3p23

Izadinia, N., \& Rasaiian, A. (2009). Capital Structure and Corporate Income Tax in Iran. Journal of Taxes, 17(4), 31-43. SID. Retrieved from http://fa.journals.sid.ir/ViewPaper.aspx?id=115188 [Persian]

Jahankhani, A. (1994). Methods of Financing the Current Situation of the Capital Market. Institute of Humanities and Cultural Studies, 9(11-12), 107-108. Retrieved October 2017, from http://www.ensani.ir/fa/content/51431/default.aspx [Persian]

Johnson, R., \& Soenen, L. (2003). Indicators of Successful Companies. European Management Journal, 21(3), 364-369. https://doi.org/10.1016/S0263-2373(03)00050-1

Kayhan, A., \& Titman, Sh. (2007). Firms Histories and Their Capital Structure. Journal of Financial Economics, 83(1), 1-32. Retrieved October 2017, from http://www.nber.org/papers/w10526

Koksal, B., \& Orman, C. (2014). Determinants of Capital Structure: Evidence from a Major Developing Economy. Small Business Economics, 44(2), 255-282. Retrieved October 2017, from https://link.springer.com/article/10.1007/s11187-014-9597-x

Kopyakova, A. (2017). Capital Structure Determinants: The Evidence from Listed and Unlisted Dutch Firms. Bachelor thesis. University of Twente. Retrieved October 2017, from http://purl.utwente.nl/essays/72748

Kordestani, G.h., \& Najafi Omran, M. (2009). Determinants of Debt Ratio: the Static Trade-off and Pecking Order Theories. Journal of Financial Research, 9(4), 73-90. Retrieved October 2017, from https://jfr.ut.ac.ir/article_27746_2787.html [Persian]

Kraus, A., \& Litzenberger, R.H. (1973). A State-Preference Model of Optimal Financial Leverage. The Journal of Finance, 28(4), 911-922. Retrieved October 2017, from http://www.jstor.org/stable/2978343

Laskin, A.V. (2017). The Handbook of Financial Communication and Investor relations (Handbook in Communication and Media). Willey-Blackwell.

Lema, T.F., \& Negash, M. (2014). Determinants of the Adjustment Speed of Capital Structure: Evidence from Developing Economies. Journal of Applied Accounting Research, 15(1), 64-99. https://doi.org/10.1108/JAAR-03-2012-0023 
Lemmon, M.L., \& Zender, J.F. (2010). Debt Capacity and Tests of Capital Structure Theories. The Journal of Financial and Quantitative Analysis, 45(5), 1161-1187. Retrieved October 2017, from http://www.jstor.org/stable/27919560

Li, H., \& Stathis, P. (2017). Determinants of Capital Structure in Australia: An Analysis of Important Factors. Managerial Finance, 43(8), 881-897. https://doi.org/10.1108/MF-02-2017-0030

Lopez-Gracia, J., \& Sogorb-Mira, F. (2008). Testing Trade-off and Pecking Order Theories Financing SMEs. Small Business Economics, 31(2), 117-136. Retrieved October 2017, from https://link.springer.com/article/10.1007\%2Fs11187-007-9088-4

Mahakud, J., \& Mukherjee, S. (2011). Determinants of Adjustment Speed of Target Capital Structure: Evidence from Indian Manufacturing Firms. International Conference on Economics and Finance Research, 4, 67-71. Retrieved October 2017, from www.ipedr.com/vol4/13-F00030.pdf

Matemilola, B.T., Bany-Ariffin, A.N., \& McGowan, C. (2013). Unobservable Effects and Firm's Capital Structure Determinants. Managerial Finance, 39(12), 1124-1137. https://doi.org/10.1108/MF-08-2012-0187

Mclean, R. (2003). Financial Management in Health Care Organization (2nd ed.). Canada: Thomson.

Miglo, A. (2016). Capital Structure in the Modern World. https://doi.org/10.1007/978-3-319-30713-8

Minton, B., \& Schrand, C. (1999). The Impact of Cash Flow Volatility on Discretionary Investment and The Costs of Debt and Equity Financing. Journal of Financial Economics, 54(3), 423-460. https://doi.org/10.1016/S0304-405X(99)00042-2

Modigliani, F., \& Miller, M.H. (1958a). The Cost of Capital, Corporate Finance and Theory of Investment. The American Economic Review, 48(3), 261-297. Retrieved October 2017, from http://www.jstor.org/stable/1809766

Myers, S.C. (1984). The Capital Structure Puzzle. Journal of Finance, 39(3), 574-592. https://doi.org/10.1111/j.1540-6261.1984.tb03646.x

Myers, S.C., \& Majluf, N.S. (1984). Corporate Financing and Investment Decisions When Firms have Information that Investors do not have. Journal of Financial Economics, 13(2), 187-221. https://doi.org/10.1016/0304-405X(84)90023-0

Oino, I., \& Ukaegbu, B. (2015). The Impact of Profitability on Capital Structure and Speed of Adjustment: An Empirical Examination of Selected Firms in Nigerian Stock Exchange. Research in International Business and Finance, 35, 1-21. https://doi.org/10.1016/j.ribaf.2015.03.004

Organization Exchange Security. (2013). Financing in the Money Market and Capital Market and the Role of Capital Companies in Iran. Retrieved October 2017, from http://www.seo.ir/Department/PLtntoeoCB-kHs1zG_CvjQ==/\%D8\%A7\%D8\%AF\%D8\%A7\%D8\%B1\%D9\%8 7-\%D8\%A8\%D8\%A7\%D8\%B2\%D8\%B1\%D8\%B3\%DB\%8C-\%D9\%86\%D9\%87\%D8\%A7\%D8\%AF\%D9\% 87\%D8\%A7\%DB\%8C-\%D9\%85\%D8\%A7\%D9\%84\%DB\%8C [Persian]

Pacheco, L. (2015). Capital Structure and Internationalization: The Case of Portuguese Industrial SMEs', Research in International Business and Finance, 38, 531-545. https://doi.org/10.1016/j.ribaf.2016.07.014

Pratt, Sh. P., \& Granbowski, R.J. (2010). Cost of Capital in Litigation: Applications and Examples (4th ed.). New Jersey: John Wiley \& Sons.

Qiu, M., \& La, B. (2010). Firm Characteristics as Determinants of Capital Structure in Australia. International Journal of the Economics of Business, 17(3), 277-287. http://dx.doi.org/10.1080/13571516.2010.513810

Rajagopal, S. (2011). The Portability of Capital Structure Theory: Do Traditional Models Fit in an Emerging Economy?. Journal of Finance and Accountancy, 1-17. Retrieved October 2017, from http://www.aabri.com/manuscripts/10654.pdf

Rajan, R., \& Zingales, L. (1995). What Do We Know About Capital Structure? Some Evidence from International Data. The Journal of Finance, 50(5), 1421-1460. Retrieved October 2017, from http://www.jstor.org/stable/2329322

Risius, J.M. (2007). Business Valuation: A Primer for the Legal Professional. Untied States: American Bar Association.

Saeedi, A., \& Mahmoodi, I. (2013). Corporate Capital Structure Decisions: Evidence from an Emerging Market. Australian Journal of Basic and Applied Science, 7(8), 875-885. Retrieved from ajbasweb.com/old/ajbas/2013/June/875-885.pdf 
Sakatan, R. (2010). The Capital Structure in Developing Countries: Saudi Arabia, pp. 1-72. Dissertation: Capital Structure in Developing Countries: Saudi Arabia. Retrieved from https://ssrn.com/abstract=2144187

Serrasqueiro, Z., \& Caetano, A. (2014). Trade-off Theory versus Pecking Order Theory: Capital Structure Decisions in Peripheral Region of Portugal. Journal of Business Economics and Management, 16(2), 445-466. http://dx.doi.org/10.3846/16111699.2012.744344

Sheri Anaqiz, S., Rahmani, A., Blue, Gh., \& Mohseni-Maleki, B. (2015). Financial Flexibility and Speed of Capital Structure Adjustment. Noor Specialized Magazine, 2, 73-88. Retrieved from http://www.noormags.ir/view/en/articlepage/1092326 [Persian]

Snedecor, G.W., \& Cochran, W.G. (1989). Statistical Methods (8th ed.). Iowa State University Press.

Supra, B., Narender, V., Jadiyappa, N., \& Girish, G.P. (2016). Speed of Adjustment of Capital Structure in Emerging Markets. Theoretical Economic Letters, 6, 534-538. Retrieved October 2017, from https://file.scirp.org/pdf/TEL_2016060915441962.pdf

Taleb, T.S. (2015). The Determinants of Capital Structure an Empirical Study of Companies listed in Palestine Exchange (2009-2014). Master Thesis, Islamic University-Gaza.

Tan-Kah-Keng, E., Wen, O.G., Li, S.L., Ling T. Y., \& Yeng, W.A. (2016). The Determinants of Capital Structure of Government Linked Companies in Malaysia. Bachelor thesis. University Tunku Abdul Rahman. Retrieved from http://eprints.utar.edu.my/2370/1/FN-2016-1307254.pdf

Ting, T.M., \& Chin, Ch.P. (2017). Determinants of Capital Structure among Textile Firms: Dynamic Panel Data Estimation. Journal of Applied Finance and Economics Policy, 1(1), 8-17. Retrieved October 2017, from http://journals.ifasra.com/index.php/jafep/article/viewFile/7/3

Trinh, T.H., \& Phuong, N.T. (2016). Effects of Financial Crisis on Capital Structure of Listed Firms in Vietnam', International Journal of Financial Research, 7(1), 66-74. https://doi.org/10.5430/ijfr.v7n1p66

Tugba, B. (2012). Capital structure and debt maturity choices of firms in developing countries. Unpublished Doctoral thesis, City University London. Retrieved October 2017, from http://openaccess.city.ac.uk/id/eprint/1073

Ukaegbu, B., \& Oino, I. (2013). Does Capital Structure and Speed of Adjustment Vary Across Developing Countries in Africa?. SSRN Electronic Journal, 1-40. https://dx.doi.org/10.2139/ssrn.2372433

Valipour, H., Almasi, M.R., \& Kaidi, S.I. (2011). Capital Structure, Average Cost of Capital and Their Changes, 3(12), 185-215. Retrieved October 2017, from http://fa.journals.sid.ir/ViewPaper.aspx?id=181521 [Persian]

Volugaris, F., Asteriou, D., \& Agiomirgianakis, G. (2007). Size and Determinants of Capital Structure in Greek Manufacturing Sector. International Review of Applied Economics, 18(2), 247-262. http://dx.doi.org/10.1080/0269217042000186714

Wald, J.K. (1999). How Firm Characteristics Affect Capital Structure: An International Comparison', The Journal of Financial Research, 22(2), 161-187. https://doi.org/10.1111/j.1475-6803.1999.tb00721.x

Wanzenried, G. (2007). Capital structure Dynamics in the UK and Continental Europe. The European Journal of Finance, 12(8), 693-716. http://dx.doi.org/10.1080/13518470500460178

Wolters, F. (2017). Capital Structure of Non-Public Listed Firms in the Last Financial Crisis: A Cross Country and Cross Industry Study. Master Thesis, Radboud University Nijmegen. Retrieved October 2017, from http://theses.ubn.ru.nl/handle/123456789/4433

Zarebski, P., \& Dimovsli, B. (2012). Determinants of Capital Structure of A-Reits and the Global Financial Crisis. Pacific Rim Property Research Journal, 18(1), 3-19. http://dx.doi.org/10.1080/14445921.2012.11104347

Zerriaa, M., \& Noubbigh, H. (2015). Determinants of Capital Structure: Evidence from Tunisian Listed Firms. International Journal of Business and Management, 10(9), 121-135. http://dx.doi.org/10.5539/ijbm.v10n9p121

Zou, H., \& Xiao, J.Z. (2006). The Financing Behavior of Listed Chinese Firms. The British Accounting Review, 38(3), 239-258. https://doi.org/10.1016/j.bar.2006.04.008

Note

Note 1: $\quad L D_{i, t+1}=L D_{i, t}+\lambda\left(\alpha X_{i, t}+L D_{i, t}\right)+\mu_{i, t+1} \rightarrow L D_{i, t+1}=L D_{i, t}+\lambda \alpha X_{i, t}-\lambda L D_{i, t}+\mu_{i, t+1} \rightarrow L D_{i, t+1}=$ $\lambda \alpha X_{i, t}+(1-\lambda) L D_{i, t}+\mu_{i, t}$ 